\title{
How frequent is altered gene expression among susceptibility genes to human complex disorders?
}

Philippe H. Jais, $M D, P h D$

\begin{abstract}
It is regularly thought that human complex disorder susceptibility genes show differences in gene expression between normal and pathologic tissues. Thus, differences of transcript amounts could be indicative of complex disorder susceptibility loci and, therefore, be used for the discovery or the validation of human susceptibility genes to complex disorders/traits. Whether human complex disorder susceptibility genes effectively display differences in transcript amounts was tested by meta-analysis of the published literature comparing transcript amounts of well-validated human susceptibility genes to complex traits/disorders. A total of 94 gene-disease associations, which were studied in at least three independent studies and showed strong evidence of positive association, were analyzed. For 23 out of these 94 well-validated gene-disease associations, 120 gene expression studies comparing normal and pathologic human tissues were found. For 60 out of these 120 gene expression studies, the difference of level expression between normal and pathologic human tissues was statistically significant. This result was highly significant, as only 6 significant results were expected randomly under the null hypothesis $(P<$ $\left.10^{-112}\right)$. A large excess of replication studies were also found, which were in agreement with the original report $\left(P=6 \times 10^{-4}\right)$. However, the overall level of expression change between normal and pathologic human tissues was relatively moderate, because only $36(60 \%)$ and 19 (31.6\%) out of the 62 statistically significant gene expression studies reached 2- or 3-fold changes in expression level, respectively. The present meta-analysis confirms statistical differences of expression levels between normal and pathologic human tissues for human susceptibility genes to complex traits/disorders. However, the levels of differences in transcript amounts appear to be relatively weak. These findings rationalize the use of gene expression for the discovery/validation of human susceptibility genes, but the weak differences of expression typically found should be taken into account for the design of such
\end{abstract} studies. Genet Med 2005:7(2):83-96.

Key Words: microarrays, RNA, expression, QTL, association.

A number of variations of human DNA are likely to alter gene transcription rates. For instance, promoter and splice junction polymorphisms, which can change transcription rates $^{1,2}$ and RNA stability, ${ }^{3}$ occur on average every 5.3 and 6.5 bases per kilobase of human DNA, respectively. ${ }^{4}$ Likewise, such DNA variations can be associated with complex traits/ disorders either directly or indirectly through linkage disequilibrium with susceptibility loci. Therefore, differences of transcript abundance between series of cases and controls can be indicative of association to susceptibility loci, rationalizing the use of differences of gene expression level as a surrogate marker for complex traits or disorders. ${ }^{5}$

The aim of the present meta-analysis was to evaluate whether complex disorder susceptibility loci show differences in gene expression between normal and affected tissues. This

From Chiasma Laboratories, Paris, France.

Philippe Jais, MD, PhD, CHIASMA, 15 rue du Petit Musc, 75004 Paris, France.

Received: June 9, 2004.

Accepted: November 3, 2004.

DOI: 10.1097/01.GIM.0000153665.55420.C3 question was addressed by meta-analysis of all studies related to well-validated human gene-disease associations that have compared transcript amounts between series of normal and pathologic tissues. The present findings clearly demonstrate that statistical differences in transcript levels of disease susceptibility genes are found between normal and pathologic human tissues. These results rationalize the use of comparative gene expression analysis for gene discovery studies. However, the relatively weak levels of differences in transcript amounts were found, which should be taken into account for the design of gene discovery studies based on gene expression studies.

\section{METHODS}

\section{Literature search and inclusion criteria}

To search for eligible studies, the MEDLINE citations up to May 2003 using the National Library of Medicine's PubMed online search engine were surveyed. The search was limited to English language literature. For gene-disease association retrieval, I combined the official symbol of the gene as defined by Human Gene Nomenclature or its alternative aliases, plus the 


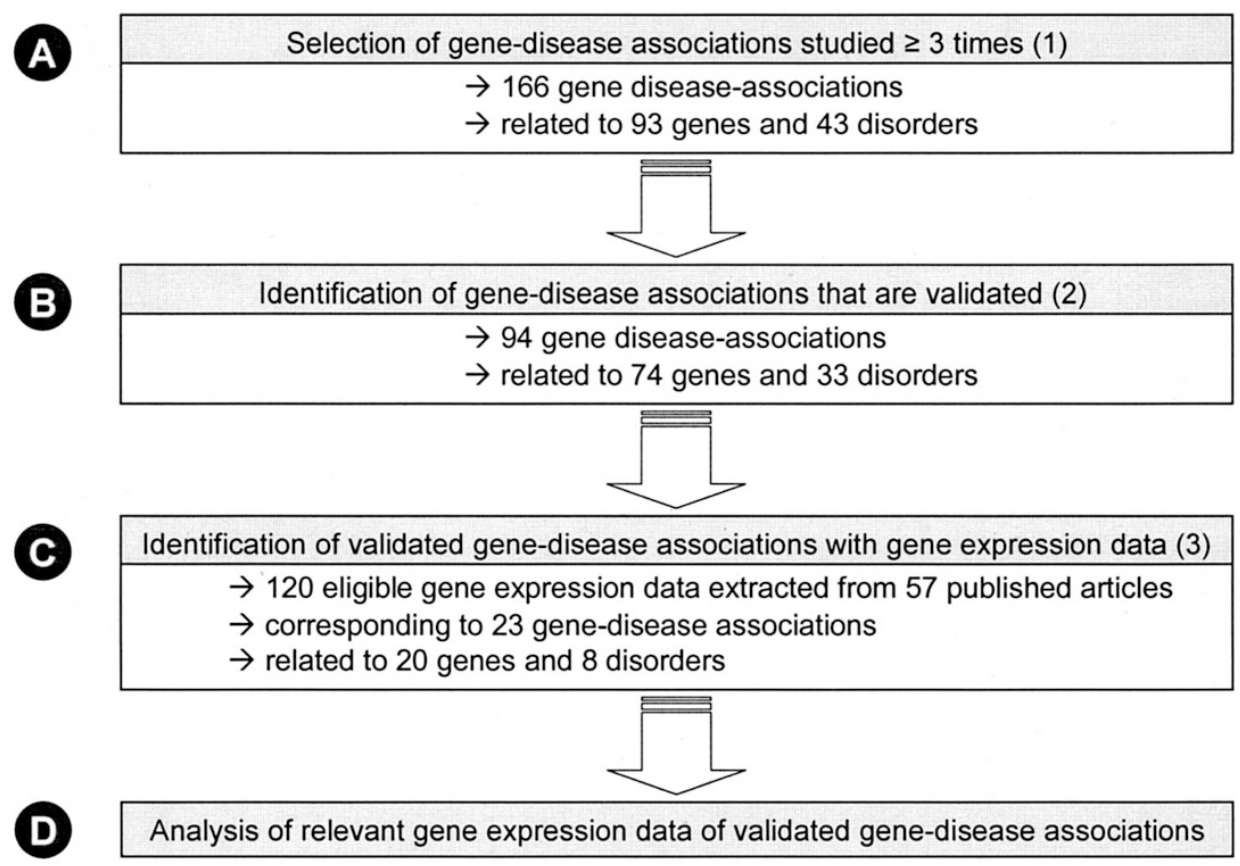

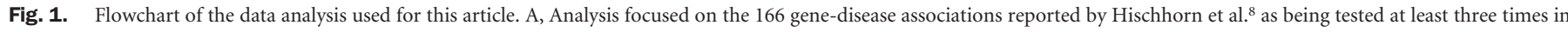

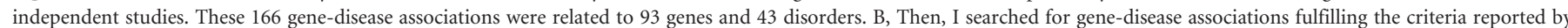

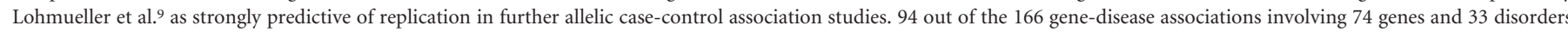

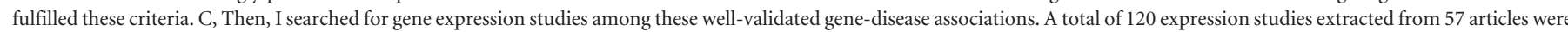

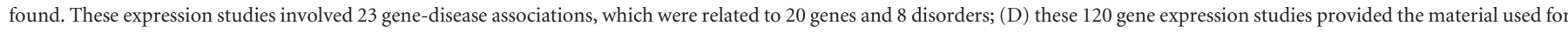
the present statistical meta-analysis.

name(s) of the disease, plus at least one of the keywords association or polymorphism or allele. For the selection of the gene expression studies, I combined the official symbol of the gene or its alternative aliases, plus the name of the disease, plus one of the keywords: transcript or mRNA or RNA or expression.

The abstracts from the literature search were screened to select relevant studies. The articles were read, and all relevant references cited in these studies were recovered to identify additional works unidentified in the PubMed screen.

\section{Selection of validated gene-disease associations}

The analysis is based on the 166 gene-disease associations reported by Hischhorn et al. ${ }^{8}$ as being tested at least three times in independent studies. These 166 gene-disease associations were related to 93 genes and 43 disorders (Fig. 1). This analysis included all published associations between human common disease or dichotomous trait and common polymorphisms (defined as having a minor allele frequency over 0.01 ) located within or in the vicinity of the investigated genes. This review excluded the polymorphisms in HLA or blood groups, as well as association studies for substance abuse and laboratory findings. In addition, only the associations between variation at single locus and susceptibility to disease in the entire population were taken into account by Hischhorn et al. ${ }^{8}$

I next focused the analysis on gene-disease associations that have been well-validated in the published literature. Therefore, I have searched among the 166 previous gene-disease associations those that fulfilled the criteria reported by Lohmueller et al. ${ }^{9}$ as strongly predictive of positive association on a sample of 25 gene-disease associations. These criteria were established on the fact that most of the 8 gene-disease associations supported by previously published meta-analysis met those criteria, whereas most of the remaining 17 did not. ${ }^{9}$ These criteria are, in addition to the initial positive study achieving $P<0.05$, at least two additional independent studies with $P<0.01$ or a single study reaching $P<0.001$. When more than one polymorphism in a gene had been studied, all polymorphisms corresponding to this gene were considered simultaneously. As a result, 94 gene-disease associations involving 74 genes and 33 disorders/traits fulfilled these conservative criteria (Fig. 1 and Table 1). Consequently, some of these genes were associated with two or more diseases (mean, 1.34; range, 1-5), such as TNF, which is involved in Alzheimer disease, obesity, type I diabetes, type II diabetes, and asthma. Interestingly, 33 out of these 74 genes (44.6\%) were also found associated to Mendelian-inherited diseases according to the Genatlas database. This strongly suggests that some genes can be responsible at the same time of a rare Mendelian-inherited form of a disorder caused by highly penetrant alleles, but also in their much more common multigenic form through less penetrant alleles. Although the molecular mechanisms associated with these differences of inheritance have not been investigated in detail, the changes due to Mendelian-inherited disorders can reasonably be expected to have more drastic effect on gene function than the variations predisposing to common multigenic forms of the disorder. 
Table 1

Gene-disease associations

\begin{tabular}{|c|c|c|c|c|c|}
\hline Gene & Disease/trait & \# OMIM & Aliases & $\begin{array}{l}\text { First positive } \\
\text { article }\end{array}$ & Mendelian disorder \\
\hline$A 2 M$ & Alzheimer's disease & 103950 & Alpha-2-macroglobulin & 10 & $\begin{array}{l}\text { 103950, emphysema with lung destruction II (macroglobulin, } \\
\text { alpha-2-deficiency) }\end{array}$ \\
\hline$A B C C 8$ & Diabetes type 2 & 600509 & Sulfonylurea receptor; SUR & 11 & 256450 , pancreatic nesidioblastosis \\
\hline$A C E^{a}$ & $\mathrm{CAD} / \mathrm{MI}$ & 106180 & Angiotensin converting enzyme; DCP1; dipeptidyl carboxypeptidase 1 & 12 & No \\
\hline$A C E$ & Hypertension & 106180 & Angiotensin converting enzyme; DCP1; dipeptidyl carboxypeptidase 1 & 13 & No \\
\hline$A C E$ & Ischemic stroke/carotid atheroma & 106180 & Angiotensin converting enzyme; DCP1; dipeptidyl carboxypeptidase 1 & 14 & No \\
\hline$A D D 1$ & Hypertension & 102680 & Alpha adducin 1 & 15 & No \\
\hline ADRB2 & Obesity & 109690 & Beta 2 adrenergic receptor & 16 & No \\
\hline$A D R B 3$ & Obesity & 109691 & Beta 3 adrenergic receptor & 17 & No \\
\hline AGTR1 & Hypertension & 106165 & Angiotensin II receptor, type 1 & 18 & No \\
\hline$A P O B$ & $\mathrm{CAD} / \mathrm{MI}$ & 107730 & Apolipoprotein B & 19 & 200100, abetalipoproteinemia \\
\hline$A P O C 1^{a}$ & Alzheimer's disease & 107710 & Apolipoprotein-C1; Apolipoprotein $\mathrm{Cl}$ & 20 & No \\
\hline$A P O E^{a}$ & Alzheimer's disease & 107741 & Apolipoprotein E & 21 & $\begin{array}{l}\text { 107741, familial dysbetalipoproteinemia, hyperlipoproteinemia type } \\
\text { III }\end{array}$ \\
\hline$A P O E$ & $\mathrm{CAD} / \mathrm{MI}$ & 107741 & Apolipoprotein E & 22 & $\begin{array}{l}\text { 107741, familial dysbetalipoproteinemia, hyperlipoproteinemia type } \\
\text { III }\end{array}$ \\
\hline$A P O E$ & Ischemic stroke & 107741 & Apolipoprotein E & 23 & $\begin{array}{l}\text { 107741, familial dysbetalipoproteinemia, hyperlipoproteinemia type } \\
\text { III }\end{array}$ \\
\hline$A P O E$ & Tacrine Response & 107741 & Apolipoprotein E & 24 & $\begin{array}{l}\text { 107741, familial dysbetalipoproteinemia, hyperlipoproteinemia type } \\
\text { III }\end{array}$ \\
\hline$A P O E$ & Overall mortality & 107741 & Apolipoprotein E & 25 & $\begin{array}{l}\text { 107741, familial dysbetalipoproteinemia, hyperlipoproteinemia type } \\
\text { III }\end{array}$ \\
\hline$A R$ & Male infertility & 313700 & Androgen receptor & 26 & 300068 , androgen insensity syndrome; 313200 , Kennedy syndrome \\
\hline$A R$ & Prostate cancer & 313700 & Androgen receptor & 27 & 300068 , androgen insensity syndrome; 313200 , Kennedy syndrome \\
\hline BCHE & Alzheimer's disease & 177400 & Butyrylcholinesterase & 28 & 177400 , postanesthetic apnea \\
\hline CCR2 & HIV infection/AIDS & 610267 & Chemokine (C-C motif) receptor 2; CKR2; CMKBR2 & 29 & No \\
\hline CCR5 & HIV infection/AIDS & 601373 & Chemokine (C-C motif) receptor 5; CKR5; CMKBR5 & 29 & No \\
\hline COL1A1 & Osteoporosis/fracture & 120140 & Collagen, type I, alpha 1 & 30 & $\begin{array}{l}130060 \text { Ehlers-Danlos syndrome TYPE VII; 166210, osteogenesis } \\
\text { imperfecta type II; } 259420 \text { type III; and } 166220 \text { type IV }\end{array}$ \\
\hline$C O M T^{a}$ & Bipolar disorder & 116790 & Catechol-O-methyltransferase & 31 & No \\
\hline COMT & Schizophrenia & 116790 & Catechol-O-methyltransferase & 32 & No \\
\hline CTLA4 & Diabetes type 1 & 123890 & Cytotoxic T-lymphocyte-associated protein 4; CD153 & 33 & No \\
\hline CTLA4 & Graves' disease & 123890 & Cytotoxic T-lymphocyte-associated protein 4; CD152 & 33 & No \\
\hline CTLA4 & Systemic lupus erythematous & 123890 & Cytotoxic T-lymphocyte-associated protein 4; CD154 & 34 & No \\
\hline CYBA & $\mathrm{CAD} / \mathrm{MI}$ & 233690 & Cytochrome b-245 alpha; p22-PHOX & 35 & 233690 , chronic granulomatous disease \\
\hline CYP11B2 & Hypertension & 124080 & Aldosterone synthase; steroid 11-beta-hydroxylase & 36 & 203400, congenital hypoaldosteronism \\
\hline CYPIA1 & Breast cancer & 108330 & Cytochrome P450, subfamily $1 \mathrm{~A}$, polypeptide 3 & 37 & No \\
\hline CYP2D6 & Parkinson's disease & 124030 & Cytochrome P450, subfamily IID, polypeptide 6 & 38 & $\begin{array}{l}\text { 124030, debrisoquine sensitivity including neuroleptic malignant } \\
\text { syndrome }\end{array}$ \\
\hline CYP2E & Lung cancer & 124040 & Cytochrome P450, subfamily IIE; CYP2E2 & 39 & No \\
\hline$D R D 2^{a}$ & Schizophrenia & 126450 & Dopamine receptor D2 & 40 & 159900 , hereditary essential myoclonus and myoclonic dystonia \\
\hline DRD3 & Clozapine response & 126451 & Dopamine receptor D3 & 41 & No \\
\hline$D R D 3^{a}$ & Schizophrenia & 126451 & Dopamine receptor D3 & 42 & No \\
\hline DRD4 & ADHD & 126452 & Dopamine receptor D4 & 43 & No \\
\hline ESR1 & Osteoporosis/fracture & 133430 & Estrogen Receptor 1 & 44 & $\begin{array}{l}\text { 133430, estrogen resistance with defect of bone maturation and } \\
\text { mineralization }\end{array}$ \\
\hline$F 2$ & Deep Venous Thrombosis & 176930 & Prothrombin; coagulation factor II & 45 & 176930, autosomal dominant dysprothrombinemia \\
\hline$F 2$ & Ischemic stroke & 176930 & Prothrombin; coagulation factor II & 46 & 176930, autosomal dominant dysprothrombinemia \\
\hline F5 & Deep Venous Thrombosis & 227400 & Coagulation factor $\mathrm{V}$ & 47 & 227400, parahemophilia \\
\hline F5 & Pre-eclampsia & 227400 & Coagulation factor $\mathrm{V}$ & 48 & 227400, parahemophilia \\
\hline F7 & $\mathrm{CAD} / \mathrm{MI}$ & 227500 & Coagulation factor VII & 49 & 227500, hypoproconvertinemia \\
\hline
\end{tabular}


Table 1

(Continued)

\begin{tabular}{|c|c|c|c|c|c|}
\hline Gene & Disease/trait & \# OMIM & Aliases & $\begin{array}{l}\text { First positive } \\
\text { article }\end{array}$ & Mendelian disorder \\
\hline FCGR2A & Systemic lupus erythematous & 1467901 & CD32; Fc IgG low affinity IIa receptor & 50 & No \\
\hline GCGR & Diabetes type 2 & 138033 & Glucagon receptor & 51 & No \\
\hline GCK & Diabetes type 2 & 138079 & Glucokinase; MODY2; hexokinase 4 & 52 & $\begin{array}{l}\text { 125853, MODY2; 602485, autosomal dominant } \\
\text { hyperinsulinism; 601410, permanent neonatal diabetes } \\
\text { mellitus }\end{array}$ \\
\hline GNB3 & Hypertension & 139130 & G-protein beta, polypeptide 3 & 53 & No \\
\hline GP1BA & $\mathrm{CAD} / \mathrm{MI}$ & 231200 & Platelet glycoprotein $\mathrm{Th}$, alpha polypeptide & 54 & 231200, Bernard-Soulier syndrome \\
\hline GSTM1 & Bladder cancer & 138350 & Glutathione S-transferase MI; glutathione S-transferase mu-1 & 55 & No \\
\hline GSTM1 & Lung cancer & 138350 & Glutathione S-transferase MI; glutathione S-transferase mu-1 & 56 & No \\
\hline$G Y S 1^{a}$ & Diabetes type 2 & 138570 & Glycogen synthase (muscle); GYS & 57 & No \\
\hline HTR2A & Anorexia & 182135 & 5-hydroxytryptamine (serotonin) receptor 2A; HTR2 & 58 & No \\
\hline HTR2A & Clozapine response & 182135 & 5-hydroxytryptamine receptor 2A; serotonin receptor 2A; HTR2 & 59 & No \\
\hline$H T R 2 A^{a}$ & Schizophrenia & 182135 & 5-hydroxytryptamine receptor $2 \mathrm{~A}$; serotonin receptor $2 \mathrm{~A}$; HTR2 & 60 & No \\
\hline ILIRA & Osteoporosis/fracture & 147810 & Interleukin-1 receptor antagonist & 61 & No \\
\hline$I L 4^{a}$ & Asthma & 147780 & Interleukin 4 & 62 & No \\
\hline$I L 4 R^{a}$ & Asthma & 147781 & Interleukin 4 receptor & 63 & No \\
\hline IL6 & Osteoporosis/fracture & 147620 & Interleukin-6; IL-6 & 64 & No \\
\hline INS & Diabetes type 1 & 176730 & Insulin & 65 & 176730, diabetes with hyperproinsulinemia \\
\hline INS & Diabetes type 2 & 176730 & Insulin & 66 & 176730 , diabetes with hyperproinsulinemia \\
\hline$I R S 1^{a}$ & Diabetes type 2 & 147545 & Insulin receptor substrate 1 & 67 & No \\
\hline ITGB3 & $\mathrm{CAD} / \mathrm{MI}$ & 173470 & Glycoprotein IIIa; integrin, beta-3; CD61 & 68 & 273800, Glanzmann thrombasthenia \\
\hline KCNN3 & Schizophrenia & 602983 & hKCa3; SKCA3; SK3; hSK3 & 69 & No \\
\hline$L E P^{a}$ & Obesity & 164160 & Leptin; OB & 70 & 164160 , severe early-onset obesity \\
\hline$L P L$ & $\mathrm{CAD} / \mathrm{MI}$ & 238600 & Lipoprotein lipase & 71 & 238600 , hyperchylomicronemia \\
\hline LTA & Multiple sclerosis & 153440 & Tumor necrosis factor beta; TNFB; Lymphotoxin-alpha & 72 & No \\
\hline MBL2 & Systemic lupus erythematous & 154545 & Mannose binding lectin; mannose binding protein; MBP1 & 73 & 154545 , recurrent infections \\
\hline MBP & Multiple sclerosis & 159430 & Myelin basic protein & 74 & No \\
\hline MTHFR & $\mathrm{CAD} / \mathrm{MI}$ & 236250 & 5,10 -methylene tetrahydrofolate reductase & 75 & 236250 , developmental delay with gait \\
\hline MTHFR & Deep Venous Thrombosis & 236250 & 5,10-methylene tetrahydrofolate reductase & 76 & 236250, developmental delay with gait \\
\hline NOS3 & $\mathrm{CAD} / \mathrm{MI}$ & 163729 & Endothelial nitric oxide synthase; ENOS & 77 & No \\
\hline PON1 & $\mathrm{CAD} / \mathrm{MI}$ & 168820 & Paraoxonase 1 & 78 & No \\
\hline$P P A R G^{a}$ & Diabetes type 2 & 601487 & $\begin{array}{l}\text { Peroxisome proliferator-activated receptor gamma; } \\
\text { PPARgamma }\end{array}$ & 79 & $\begin{array}{l}\text { 604367, insulin resistance with non insulin dependent } \\
\text { diabetes mellitus }\end{array}$ \\
\hline$P P A R G^{a}$ & Obesity & 601487 & $\begin{array}{l}\text { Peroxisome proliferator-activated receptor gamma; } \\
\text { PPARgamma }\end{array}$ & 79 & $\begin{array}{l}\text { 604367, insulin resistance with non insulin dependent } \\
\text { diabetes mellitus }\end{array}$ \\
\hline PRNP & Creutzfeldt-Jakob disease & 176640 & Prion protein; PRP & 80 & 123400, Creutzfeldt-Jakob disease \\
\hline PSEN1 ${ }^{a}$ & Alzheimer's disease & 104311 & Presenilin 1; PS1; AD3 & 81 & 104300, Alzheimer disease \\
\hline RSTN & Diabetes type 2 & 605565 & Resistin; FIZZ3 & 82 & No \\
\hline SERPINA1 & COPD/emphysema & 107400 & Alpha-1-antitrypsin; protease inhibitor I; PI & 83 & 107400 , severe emphysema; 107400 , hemorrhagic diathesis \\
\hline SERPINA3 & Alzheimer's disease & 107280 & Alpha-1-antichymotrypsin; AACT & 84 & 107280, severe emphysema \\
\hline SERPINA $8^{a}$ & $\mathrm{CAD} / \mathrm{MI}$ & 106150 & Angiotensinogen; AGT & 85 & No \\
\hline SERPINA ${ }^{a}$ & Hypertension & 106150 & Angiotensinogen; AGT & 86 & No \\
\hline SERPINE1 & $\mathrm{CAD} / \mathrm{MI}$ & 173360 & Plasminogen activator inhibitor 1 ; PAI 1 & 87 & 173360 , bleeding diathesis; 173360 , recurrent thrombosis \\
\hline SLC2A1 & Diabetes type 2 & 138140 & GLUT1; glucose transporter 1 & 88 & $\begin{array}{l}\text { 138140, infantile seizures with microcephaly and } \\
\text { hypoglycorrhachia }\end{array}$ \\
\hline SLC6A4 $4^{a}$ & Bipolar disorder & 182138 & SERT; Serotonin transporter; $5 \mathrm{HTT}$ & 89 & No \\
\hline$T N F$ & Asthma & 191160 & Tumor necrosis factor alpha; TNFA & 90 & No \\
\hline$T N F$ & Diabetes type 1 & 191160 & Tumor necrosis factor alpha; TNFA & 93 & No \\
\hline$T N F^{a}$ & Diabetes type 2 & 191160 & Tumor necrosis factor alpha; TNFA & 94 & No \\
\hline$T N F^{a}$ & Obesity & 191160 & Tumor necrosis factor alpha; TNFA & 91 & No \\
\hline
\end{tabular}


Table 1

(Continued)

\begin{tabular}{|c|c|c|c|c|c|}
\hline Gene & Disease/trait & \# OMIM & Aliases & $\begin{array}{c}\text { First positive } \\
\text { article }\end{array}$ & Mendelian disorder \\
\hline$T N F$ & Psoriasis/psoriatic arthritis & 191160 & Tumor necrosis factor alpha; TNFA & 92 & No \\
\hline TP53 & Head and neck cancer & 191170 & Tumor necrosis factor alpha; TNFA & 95 & 151623, Li-Fraumeni syndrome \\
\hline$U C P 1^{a}$ & Obesity & 113730 & Uncoupling protein 1 & 96 & No \\
\hline$U C P 2^{a}$ & Obesity & 601693 & Uncoupling protein 2 & 97 & No \\
\hline$U C P 3^{a}$ & Obesity & 602044 & Uncoupling protein 3 & 98 & 602044 , severe obesity and type 2 diabetes mellitus \\
\hline$V D R$ & Osteoporosis/fracture & 601769 & Vitamin D receptor & 99 & 277440 , vitamin D-dependent rickets \\
\hline$V L D L R$ & Alzheimer's disease & 192977 & Very low density lipoprotein receptor & 100 & No \\
\hline
\end{tabular}

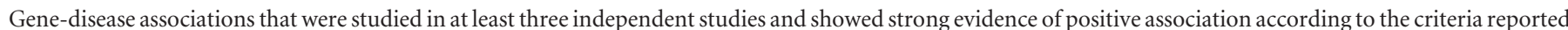

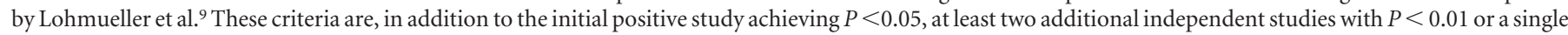
study reaching $P<0.001$.

${ }^{a_{T}}$ The 23 gene-disease associations for which gene expression has been studied (see Table 2).

\section{Gene expression studies}

Subsequently, I searched for published gene expression studies among the 94 well-validated gene-disease associations (Fig. 1). All studies based on quantitative gene expression methods were used for analysis, including semiquantitative RT-PCR, competitive RT-PCR, real-time quantitative PCR, RT-PCR ELISA, branched DNA, cDNA or oligonucleotide microarrays, quantitative Northern-blot, dot-blot, RNase protection assay, serial analysis of gene expression (SAGE), and quantitative in situ hybridization. No relevant microarray data were found and used in the present analysis. In some articles, several genes and/or methods of quantification have been assayed simultaneously, the results of which were treated separately. Only the studies providing enough details to recalculate the distribution of expression in case and control groups were selected for analysis. In addition, the studies with less than five controls or five cases were excluded for analysis because poor reliability $(n=7)$. In total, 120 expression studies extracted from 57 published articles were reviewed (Fig. 1). Consequently, some articles investigated simultaneously the expression of several genes. These 120 gene expression studies were related to 23 gene-disease associations, which correspond to 20 genes and 8 disorders (Table 2). Twelve out of these 23 gene-disease associations were screened for allelic association before gene expression studies, whereas 11 were screened for allelic association following gene expression studies. In 62 out of these 120 expression studies, the values of control and case groups were established using the figures of the original publication as details were lacking in the text of the article. In these cases, each value was assessed blindly at least three times using maximum magnified copies of the figures.

\section{Statistical analysis}

For each gene expression study, the statistical difference between case and control groups was assessed by unpaired two-tailed Student's t-test using untransformed original variables. Statistical comparisons were considered significant at $P<0.05$.
To test the effects of various parameters on the gene expression ratio, a univariate analysis by the linear model procedure using type III sums of squares model was performed. Multivariate analysis was achieved by logistic regression model with a forward stepwise search. In both univariate and multivariate analysis, the expression criteria used for analysis was the gene expression threshold below or above 2-fold change between case and control samples.

Statistical analyses were performed with the SPSS 11.5 software (SPSS Inc., Chicago, IL).

\section{RESULTS AND DISCUSSION}

The present meta-analysis aimed to determine whether well-validated human complex disorder susceptibility genes show differences in gene expression between normal and pathologic tissues. Therefore, the published literature was first screened to select well-validated gene-disease associations for complex human traits/disorders. The analysis was based on a set of 166 gene-disease associations reported by Hischhorn et al. ${ }^{8}$ as being studied in at least three different studies. Then, the published literature up to May 2003 was screened to select which of these 166 gene-associations fulfilled the criteria reported by Lohmueller et al. ${ }^{9}$ as strongly predictive of future replication. A total of 74 genes and 33 disorders involved in 94 gene-disease associations fulfilled these criteria (Fig. 1 and Table 1).

Then, these genetically well-validated genes were analyzed for differential transcript expression in pathologic conditions. In total, 120 expression records involved in 23 gene-disease associations were found (Fig. 1). For each study, the statistical difference of gene expression was calculated by unpaired twotailed Student $t$ test using the original data set (Table 2). From these 120 gene expression studies, 60 (50\%) achieved $P<0.05$, which should be compared to 6.0 significant results expected randomly under the null hypothesis of no gene expression change. This result was highly significant, as the nominal value obtained by reference to the $\chi^{2}$-distribution was 513.4 ( $\chi^{2}$-test, 1 degree of freedom; $P<10^{-112}$ ). In theory, publication bias 
Table 2

Details of gene expression studies comparing normal and pathological human tissues for the 23 well-validated human susceptibility genes to complex disorders/ traits (see Table 1)

\begin{tabular}{|c|c|c|c|c|c|c|c|c|c|c|c|c|}
\hline Gene & Disease/trait & Country & mRNA isoform & Tissue & $\begin{array}{l}\text { Main phenotype } \\
\text { of controls }\end{array}$ & $\begin{array}{l}\text { No. of } \\
\text { controls }\end{array}$ & $\begin{array}{l}\text { Main phenotype } \\
\text { of cases }\end{array}$ & $\begin{array}{l}\text { No. of } \\
\text { cases }\end{array}$ & $\begin{array}{l}\text { Method of } \\
\text { measure }\end{array}$ & Ratio & $P$ value & Ref. \\
\hline$A C E$ & $\mathrm{CAD} / \mathrm{MI}$ & Italy & Canonical & $\begin{array}{l}\text { Heart, left } \\
\quad \text { ventricular wall }\end{array}$ & $\begin{array}{l}\text { Controls with normal } \\
\text { coronarography }\end{array}$ & 21 & Individuals with stable angina & 32 & In-situ hybridization & 1,26 & $5.61 \mathrm{E}-02$ & 101 \\
\hline$A C E$ & $\mathrm{CAD} / \mathrm{MI}$ & Italy & Canonical & $\begin{array}{l}\text { Heart, left } \\
\quad \text { ventricular wall }\end{array}$ & $\begin{array}{l}\text { Controls with normal } \\
\text { coronarography }\end{array}$ & 21 & Individuals with unstable angina & 35 & In-situ hybridization & 2,02 & $1.16 \mathrm{E}-05$ & 101 \\
\hline APOC1 & $\begin{array}{l}\text { Alzheimer's } \\
\text { disease }\end{array}$ & Canada & Canonical & $\begin{array}{l}\text { Brain, prefrontal } \\
\quad \text { cortex }\end{array}$ & $\begin{array}{l}\text { Controls without dementia and } \\
\text { neuropathological change to } \\
\text { Alzheimer disease }\end{array}$ & 11 & $\begin{array}{l}\text { Individuals with Alzheimer disease with } \\
\text { neuropathological changes }\end{array}$ & 19 & RNase Protection Assay & 0,57 & $5.55 \mathrm{E}-02$ & 102 \\
\hline$A P O E$ & $\begin{array}{l}\text { Alzheimer's } \\
\text { disease }\end{array}$ & Japan & Canonical & Skin fibroblasts & Controls without dementia & 10 & $\begin{array}{l}\text { Individuals with Alzheimer disease } \\
\text { according to DSM-IIIR criteria }\end{array}$ & 18 & $\begin{array}{l}\text { Quantitative Northern- } \\
\text { blot }\end{array}$ & 0,63 & $1.04 \mathrm{E}-03$ & 103 \\
\hline$A P O E$ & $\begin{array}{l}\text { Alzheimer's } \\
\text { disease }\end{array}$ & Canada & Canonical & $\begin{array}{l}\text { Brain, prefrontal } \\
\quad \text { cortex }\end{array}$ & $\begin{array}{l}\text { Controls without dementia and } \\
\text { neuropathological change to } \\
\text { Alzheimer disease }\end{array}$ & 11 & $\begin{array}{l}\text { Individuals with Alzheimer disease with } \\
\text { neuropathological changes }\end{array}$ & 20 & RNase Protection Assay & 0,65 & $1.78 \mathrm{E}-02$ & 102 \\
\hline$A P O E$ & $\begin{array}{l}\text { Alzheimer's } \\
\text { disease }\end{array}$ & Japan & Canonical & $\begin{array}{l}\text { Brain, temporal } \\
\quad \text { cortex }\end{array}$ & $\begin{array}{l}\text { Controls with neurological } \\
\text { disease without dementia }\end{array}$ & 20 & $\begin{array}{l}\text { Individuals with sporadic Alzheimer } \\
\text { disease }\end{array}$ & 27 & Quantitative RT-PCR & 1,42 & $3,24 \mathrm{E}-02$ & 104 \\
\hline$A P O E$ & $\begin{array}{l}\text { Alzheimer's } \\
\text { disease }\end{array}$ & USA & Canonical & Brain, hippocampus & $\begin{array}{l}\text { Controls with non-Alzheimer } \\
\text { neurological disorder }\end{array}$ & 9 & Individuals with Alzheimer disease & 7 & In-situ hybridization & 1,70 & $2.51 \mathrm{E}-09$ & 105 \\
\hline COMT & Schizophrenia & USA & Canonical & $\begin{array}{l}\text { Brain, frontal } \\
\text { superior gyrus }\end{array}$ & $\begin{array}{l}\text { Controls without history of } \\
\text { psychiatric disorder }\end{array}$ & 10 & $\begin{array}{l}\text { Schizophrenia not treated with } \\
\text { antipsychotics }\end{array}$ & 14 & Competitive RT-PCR & 2,13 & $8.85 \mathrm{E}-02$ & 106 \\
\hline COMT & Schizophrenia & USA & Canonical & $\begin{array}{l}\text { Brain, middle } \\
\text { temporal gyrus }\end{array}$ & $\begin{array}{l}\text { Controls without history of } \\
\text { psychiatric disorder }\end{array}$ & 10 & $\begin{array}{l}\text { Schizophrenia not treated with } \\
\text { antipsychotics }\end{array}$ & 13 & Competitive RT-PCR & 0,50 & $4.72 \mathrm{E}-02$ & 106 \\
\hline COMT & Schizophrenia & USA & Canonical & $\begin{array}{l}\text { Brain, superior } \\
\text { temporal gyrus }\end{array}$ & $\begin{array}{l}\text { Controls without history of } \\
\text { psychiatric disorder }\end{array}$ & 10 & $\begin{array}{l}\text { Schizophrenia not treated with } \\
\text { antipsychotics }\end{array}$ & 9 & Competitive RT-PCR & 0,74 & $4.87 \mathrm{E}-01$ & 106 \\
\hline DRD2 & Schizophrenia & $\begin{array}{l}\text { United } \\
\text { Kingdom }\end{array}$ & $\begin{array}{l}\text { DRD2 short } \\
\text { isoform }\end{array}$ & $\begin{array}{l}\text { Brain, ventro orbital } \\
\text { gyrus }\end{array}$ & Controls with no details & 11 & Schizophrenics with no details & 11 & Quantitative RT-PCR & 1,39 & $8.72 \mathrm{E}-03$ & 107 \\
\hline DRD2 & Schizophrenia & $\begin{array}{l}\text { United } \\
\text { Kingdom }\end{array}$ & $\begin{array}{l}\text { DRD2 long } \\
\text { isoform }\end{array}$ & $\begin{array}{l}\text { Brain, ventro orbital } \\
\text { gyrus }\end{array}$ & Controls with no details & 11 & Schizophrenics with no details & 11 & Quantitative RT-PCR & 1,55 & $2.84 \mathrm{E}-03$ & 107 \\
\hline DRD2 & Schizophrenia & $\begin{array}{l}\text { United } \\
\text { Kingdom }\end{array}$ & $\begin{array}{l}\text { DRD2 short } \\
\text { isoform }\end{array}$ & $\begin{array}{l}\text { Brain, inferior } \\
\text { temporal gyrus }\end{array}$ & Controls with no details & 13 & Schizophrenics with no details & 9 & Quantitative RT-PCR & 1,39 & $2.10 \mathrm{E}-02$ & 107 \\
\hline DRD2 & Schizophrenia & $\begin{array}{l}\text { United } \\
\text { Kingdom }\end{array}$ & $\begin{array}{l}\text { DRD2 long } \\
\text { isoform }\end{array}$ & $\begin{array}{l}\text { Brain, inferior } \\
\text { temporal gyrus }\end{array}$ & Controls with no details & 13 & Schizophrenics with no details & 9 & Quantitative RT-PCR & 1,38 & $5.38 \mathrm{E}-02$ & 107 \\
\hline DRD2 & Schizophrenia & $\begin{array}{l}\text { United } \\
\quad \text { Kingdom }\end{array}$ & $\begin{array}{l}\text { DRD2 short } \\
\text { isoform }\end{array}$ & $\begin{array}{l}\text { Brain, polar frontal } \\
\text { cortex }\end{array}$ & Controls with no details & 19 & Schizophrenics with no details & 13 & Quantitative RT-PCR & 0,97 & $7.75 \mathrm{E}-01$ & 107 \\
\hline DRD2 & Schizophrenia & $\begin{array}{l}\text { United } \\
\text { Kingdom }\end{array}$ & $\begin{array}{l}\text { DRD2 long } \\
\text { isoform }\end{array}$ & $\begin{array}{l}\text { Brain, polar frontal } \\
\text { cortex }\end{array}$ & Controls with no details & 19 & Schizophrenics with no details & 13 & Quantitative RT-PCR & 0,97 & $8.08 \mathrm{E}-01$ & 107 \\
\hline DRD2 & Schizophrenia & $\begin{array}{l}\text { United } \\
\text { Kingdom }\end{array}$ & $\begin{array}{l}\text { DRD2 short } \\
\text { isoform }\end{array}$ & $\begin{array}{l}\text { Brain, caudate } \\
\text { nucleus }\end{array}$ & Controls with no details & 15 & Schizophrenics with no details & 9 & Quantitative RT-PCR & 1,60 & $6.79 \mathrm{E}-02$ & 107 \\
\hline DRD2 & Schizophrenia & $\begin{array}{l}\text { United } \\
\text { Kingdom }\end{array}$ & $\begin{array}{l}\text { DRD2 long } \\
\text { isoform }\end{array}$ & $\begin{array}{l}\text { Brain, caudate } \\
\text { nucleus }\end{array}$ & Controls with no details & 15 & Schizophrenics with no details & 9 & Quantitative RT-PCR & 1,98 & $7.03 \mathrm{E}-02$ & 107 \\
\hline DRD2 & Schizophrenia & Canada & $\begin{array}{l}\text { DRD2 long and } \\
\text { short isoforms }\end{array}$ & Brain, frontal cortex & $\begin{array}{l}\text { Controls without psychiatric } \\
\text { disorder }\end{array}$ & 7 & $\begin{array}{l}\text { Schizophrenics according to DSM-IV } \\
\text { criteria treated or not with } \\
\text { neuroleptics }\end{array}$ & 11 & Competitive RT-PCR & 0,20 & $7.44 \mathrm{E}-03$ & 108 \\
\hline DRD2 & Schizophrenia & Canada & $\begin{array}{l}\text { DRD2 long } \\
\text { isoform }\end{array}$ & Brain, frontal cortex & $\begin{array}{l}\text { Controls without psychiatric } \\
\text { disorder }\end{array}$ & 7 & $\begin{array}{l}\text { Schizophrenics according to DSM-IV } \\
\text { criteria treated or not with } \\
\text { neuroleptics }\end{array}$ & 7 & Competitive RT-PCR & 1,86 & $6.05 \mathrm{E}-02$ & 108 \\
\hline DRD3 & Schizophrenia & Israel & Canonical & Lymphocytes & $\begin{array}{l}\text { Controls without psychiatric } \\
\text { disorder according to DSM- } \\
\text { IV criteria }\end{array}$ & 6 & $\begin{array}{l}\text { Schizophrenics according to DSM-IV } \\
\text { criteria treated or not }\end{array}$ & 6 & PCR-Elisa & 0,81 & $3.01 \mathrm{E}-01$ & 109 \\
\hline DRD3 & Schizophrenia & Israel & Canonical & Lymphocytes & $\begin{array}{l}\text { Controls without psychiatric } \\
\text { disorder according to DSM- } \\
\text { IV criteria }\end{array}$ & 14 & $\begin{array}{l}\text { Schizophrenics according to DSM-IV } \\
\text { criteria treated or not }\end{array}$ & 14 & Quantitative RT-PCR & 3,70 & $5.77 \mathrm{E}-02$ & 109 \\
\hline DRD3 & Schizophrenia & Korea & Canonical & Lymphocytes & $\begin{array}{l}\text { Controls without psychiatric } \\
\text { disorder according to DSM- } \\
\text { IV criteria }\end{array}$ & 31 & $\begin{array}{l}\text { Schizophrenics naive or free of } \\
\text { neuroleptic therapy }\end{array}$ & 43 & Real-time RT-PCR & 7,32 & $1.28 \mathrm{E}-24$ & 110 \\
\hline GYS1 & Diabetes type 2 & France & Canonical & Skeletal muscle & $\begin{array}{l}\text { Controls with normal glucose } \\
\text { tolerance and no family } \\
\text { history of diabetes }\end{array}$ & 9 & Diabetics type 2 & 8 & Competitive RT-PCR & 0,56 & $1.90 \mathrm{E}-02$ & 111 \\
\hline GYS1 & Diabetes type 2 & France & Canonical & Skeletal muscle & $\begin{array}{l}\text { Lean controls with normal } \\
\text { glucose tolerance }\end{array}$ & 17 & Diabetics type 2 & 9 & Competitive RT-PCR & 0,73 & $2.37 \mathrm{E}-01$ & 112 \\
\hline GYS1 & Diabetes type 2 & France & Canonical & Skeletal muscle & $\begin{array}{l}\text { Obese individuals with normal } \\
\text { glucose tolerance }\end{array}$ & 9 & Diabetics type 2 & 9 & Competitive RT-PCR & 0,66 & $1.17 \mathrm{E}-01$ & 112 \\
\hline
\end{tabular}


Table 2

(Continued)

\begin{tabular}{|c|c|c|c|c|c|c|c|c|c|c|c|c|}
\hline Gene & Disease/trait & Country & $\begin{array}{l}\text { mRNA } \\
\text { isoform }\end{array}$ & Tissue & $\begin{array}{l}\text { Main phenotype } \\
\text { of controls }\end{array}$ & $\begin{array}{l}\text { No. of } \\
\text { controls }\end{array}$ & $\begin{array}{l}\text { Main phenotype } \\
\text { of cases }\end{array}$ & $\begin{array}{c}\text { No. of } \\
\text { cases }\end{array}$ & $\begin{array}{l}\text { Method of } \\
\text { measure }\end{array}$ & Ratio & $P$ value & Ref. \\
\hline GYS1 & Diabetes type 2 & USA & Canonical & Skeletal muscle & $\begin{array}{l}\text { Non-diabetic controls, non- } \\
\text { obese }\end{array}$ & 8 & Diabetics type 2 with obesity & 11 & RNase protection assay & 0,69 & $5.09 \mathrm{E}-02$ & 113 \\
\hline GYS1 & Diabetes type 2 & Sweden & Canonical & Skeletal muscle & Non-diabetic controls & 12 & Diabetics type 2 & 12 & $\begin{array}{l}\text { Primer-dropping RT- } \\
\text { PCR }\end{array}$ & 1,43 & $9.21 \mathrm{E}-03$ & 114 \\
\hline GYS1 & Diabetes type 2 & Finland & Canonical & Skeletal muscle & Non-diabetic controls & 17 & Diabetes type 2 & 14 & Dot-blot & 0,88 & $4.90 \mathrm{E}-02$ & 115 \\
\hline GYS1 & Diabetes type 2 & Denmark & Canonical & Skeletal muscle & $\begin{array}{l}\text { Controls with normal glucose } \\
\text { tolerance and no family } \\
\text { history of diabetes }\end{array}$ & 14 & Diabetics type 2 & 14 & $\begin{array}{l}\text { Quantitative Northern- } \\
\text { blot }\end{array}$ & 0,72 & $6.81 \mathrm{E}-09$ & 116 \\
\hline GYS1 & Diabetes type 2 & Denmark & Canonical & Skeletal muscle & $\begin{array}{l}\text { Controls without diabetes and } \\
\text { family history of diabetes }\end{array}$ & 19 & Diabetics type 2 & 19 & $\begin{array}{l}\text { Quantitative Northern- } \\
\text { blot }\end{array}$ & 0,73 & $3.76 \mathrm{E}-03$ & 117 \\
\hline HTR2A & Schizophrenia & $\begin{array}{l}\text { United } \\
\text { Kingdom }\end{array}$ & Canonical & $\begin{array}{l}\text { Brain, prefrontal } \\
\text { cortex }\end{array}$ & Controls with no details & 12 & Schizophrenics with no details & 12 & In-situ hybridization & 0,52 & $1.13 \mathrm{E}-04$ & 118 \\
\hline HTR2A & Schizophrenia & $\begin{array}{l}\text { United } \\
\text { Kingdom }\end{array}$ & Canonical & $\begin{array}{l}\text { Brain, cingulate } \\
\text { cortex }\end{array}$ & Controls with no details & 11 & Schizophrenics with no details & 9 & In-situ hybridization & 0,37 & $6.42 \mathrm{E}-04$ & 118 \\
\hline HTR2A & Schizophrenia & $\begin{array}{l}\text { United } \\
\text { Kingdom }\end{array}$ & Canonical & Brain, dentate gyrus & Controls with no details & 13 & Schizophrenics with no details & 11 & In-situ hybridization & 0,39 & $1.05 \mathrm{E}-03$ & 118 \\
\hline HTR2A & Schizophrenia & $\begin{array}{l}\text { United } \\
\text { Kingdom }\end{array}$ & Canonical & $\begin{array}{l}\text { Brain, superior } \\
\text { temporal gyrus }\end{array}$ & Controls with no details & 13 & Schizophrenics with no details & 7 & In-situ hybridization & 0,52 & $9.57 \mathrm{E}-03$ & 118 \\
\hline HTR2A & Schizophrenia & $\begin{array}{l}\text { United } \\
\text { Kingdom }\end{array}$ & Canonical & $\begin{array}{l}\text { Brain, } \\
\text { parahippocampal } \\
\text { gyrus }\end{array}$ & Controls with no details & 8 & Schizophrenics with no details & 10 & In-situ hybridization & 0,86 & $4.14 \mathrm{E}-01$ & 118 \\
\hline HTR2A & Schizophrenia & USA & Canonical & $\begin{array}{r}\text { Brain, superior } \\
\text { frontal gyrus }\end{array}$ & $\begin{array}{l}\text { Controls without psychiatric } \\
\text { disorder according to DSM- } \\
\text { IIIR criteria }\end{array}$ & 14 & $\begin{array}{l}\text { Schizophrenics according to DSM-IIIR } \\
\text { criteria untreated with neuroleptics } \\
\text { (>26 weeks) }\end{array}$ & 7 & Competitive RT-PCR & 0,40 & $3.31 \mathrm{E}-02$ & 119 \\
\hline IL4 & Asthma & USA & $\begin{array}{r}\text { IL4 delta2 } \\
\text { isoform }\end{array}$ & Bronchial samples & $\begin{array}{l}\text { Non-asthmatic controls with or } \\
\text { without atopy }\end{array}$ & 7 & Asthmatics with or without atopy & 9 & Quantitative RT-PCR & 3,49 & 8.23E-02 & 120 \\
\hline IL4 & Asthma & USA & Canonical & Bronchial samples & $\begin{array}{l}\text { Non-asthmatic controls with or } \\
\text { without atopy }\end{array}$ & 7 & Asthmatics with or without atopy & 9 & Competitive RT-PCR & 0,78 & $4.88 \mathrm{E}-01$ & 120 \\
\hline IL4 & Asthma & Switzerland & Canonical & Bronchial samples & Non-atopic controls & 8 & Non-atopic asthma & 10 & Competitive RT-PCR & 2,60 & $6.70 \mathrm{E}-03$ & 121 \\
\hline IL4 & Asthma & Switzerland & Canonical & Bronchial samples & Atopic controls & 9 & Atopic asthmatics & 10 & Quantitative RT-PCR & 2,08 & $1.61 \mathrm{E}-01$ & 121 \\
\hline IL4 & Asthma & Switzerland & Canonical & Bronchial samples & Non-atopic controls & 6 & Non-atopic asthmatics & 10 & Quantitative RT-PCR & 11,30 & $4.20 \mathrm{E}-03$ & 121 \\
\hline IL4 & Asthma & Switzerland & Canonical & Bronchial samples & Atopic controls & 5 & Atopic asthmatics & 9 & In-situ hybridization & 4,77 & $1.73 \mathrm{E}-01$ & 121 \\
\hline IL4 & Asthma & Canada & Canonical & Bronchial samples & Non-atopic controls & 8 & Atopic asthmatics & 9 & In-situ hybridization & 5,92 & $3.96 \mathrm{E}-05$ & 122 \\
\hline IL4 & Asthma & Canada & Canonical & $\begin{array}{l}\text { Bronchial samples, } \\
\text { airways }<2 \mathrm{~mm}\end{array}$ & $\begin{array}{l}\text { Non-asthmatics controls, } \\
\text { bronchial carcinoma }\end{array}$ & 10 & Asthmatics with bronchial carcinoma & 6 & In-situ hybridization & 6,27 & $4.46 \mathrm{E}-08$ & 123 \\
\hline IL4 & Asthma & Canada & Canonical & $\begin{array}{l}\text { Bronchial samples, } \\
\quad \text { airways }>2 \mathrm{~mm}\end{array}$ & $\begin{array}{l}\text { Non-asthmatics controls, } \\
\text { bronchial carcinoma }\end{array}$ & 10 & Asthmatics with bronchial carcinoma & 6 & In-situ hybridization & 5,43 & $1.40 \mathrm{E}-08$ & 123 \\
\hline IL4 & Asthma & Canada & Canonical & Sputum & $\begin{array}{l}\text { Non-atopic non asthmatic } \\
\text { controls }\end{array}$ & 10 & Atopic asthmatics & 13 & In-situ hybridization & 8,85 & 3.77E-08 & 124 \\
\hline IL4 & Asthma & $\begin{array}{l}\text { United } \\
\text { Kingdom }\end{array}$ & Canonical & $\begin{array}{l}\text { Bronchoalveolar } \\
\text { lavage cells }\end{array}$ & $\begin{array}{l}\text { Non-atopic non-asthmatic } \\
\text { controls }\end{array}$ & 10 & Atopic asthmatics & 10 & In-situ hybridization & 5,75 & $4.02 \mathrm{E}-07$ & 125 \\
\hline IL4R & Asthma & Canada & Canonical & Bronchial samples & Atopic non-asthmatic controls & 7 & Atopic asthmatics & 8 & In-situ hybridization & 2,25 & $2.89 \mathrm{E}-04$ & 126 \\
\hline IL4R & Asthma & Canada & Canonical & Bronchial samples & $\begin{array}{l}\text { Non-atopic non-asthmatic } \\
\text { controls }\end{array}$ & 6 & Non-atopic asthmatics & 9 & In-situ hybridization & 2,12 & $6.90 \mathrm{E}-03$ & 126 \\
\hline IRS1 & Diabetes type 2 & France & Canonical & Skeletal muscle & $\begin{array}{l}\text { Controls with normal glucose } \\
\text { tolerance and no family } \\
\text { history of diabetes }\end{array}$ & 9 & Diabetics type 2 & 8 & In-situ hybridization & 0,60 & 4.29E-02 & 111 \\
\hline IRS1 & Diabetes type 2 & France & Canonical & Skeletal muscle & $\begin{array}{l}\text { Lean controls with normal } \\
\text { glucose tolerance }\end{array}$ & 17 & Diabetics type 4 & 9 & Competitive RT-PCR & 1,32 & $2.97 \mathrm{E}-01$ & 112 \\
\hline IRS1 & Diabetes type 2 & France & Canonical & Skeletal muscle & $\begin{array}{l}\text { Obese individuals with normal } \\
\text { glucose tolerance }\end{array}$ & 9 & Diabetes type 2 & 9 & Competitive RT-PCR & 1,10 & $6.45 \mathrm{E}-01$ & 112 \\
\hline$L E P$ & Obesity & Canada & Canonical & Omental fat & $\begin{array}{l}\text { Lean controls }(\mathrm{BMI}<27 \mathrm{~kg} / \\
\left.\mathrm{m}^{2}\right)\end{array}$ & 11 & Obese individuals $\left(\mathrm{BMI}>30 \mathrm{~kg} / \mathrm{m}^{2}\right)$ & 12 & Competitive RT-PCR & 2,68 & $1.32 \mathrm{E}-08$ & 127 \\
\hline$L E P$ & Obesity & Austia & Canonical & Omental fat & $\begin{array}{l}\text { Lean controls without major } \\
\text { illness }\end{array}$ & 17 & Obese individuals $\left(\mathrm{BMI}>30 \mathrm{~kg} / \mathrm{m}^{2}\right.$ ) & 111 & Quantitative RT-PCR & 2,78 & $1.23 \mathrm{E}-03$ & 128 \\
\hline LEP & Obesity & $\begin{array}{l}\text { United } \\
\text { Kingdom }\end{array}$ & Canonical & Omental fat & $\begin{array}{l}\text { Lean controls }(\mathrm{BMI}<25 \mathrm{~kg} / \\
\left.\mathrm{m}^{2}\right) \text { without diabetes }\end{array}$ & 14 & $\begin{array}{l}\text { Obese or overweight individuals (BMI > } \\
27 \mathrm{~kg} / \mathrm{m}^{2} \text { ) without diabetes }\end{array}$ & 9 & $\begin{array}{l}\text { Quantitative Northern- } \\
\text { blot }\end{array}$ & 1,80 & $8.18 \mathrm{E}-02$ & 129 \\
\hline$L E P$ & Obesity & USA & Canonical & Subcutaneous fat & $\begin{array}{l}\text { Lean controls }(\mathrm{BMI}<25 \mathrm{~kg} / \\
\left.\mathrm{m}^{2}\right)\end{array}$ & 8 & Obese individuals $\left(\mathrm{BMI}>30 \mathrm{~kg} / \mathrm{m}^{2}\right)$ & 8 & Quantitative RT-PCR & 1,72 & $1.64 \mathrm{E}-03$ & 130 \\
\hline
\end{tabular}


Table 2

(Continued)

\begin{tabular}{|c|c|c|c|c|c|c|c|c|c|c|c|c|}
\hline Gene & Disease/trait & Country & $\begin{array}{l}\text { mRNA } \\
\text { isoform }\end{array}$ & Tissue & $\begin{array}{l}\text { Main phenotype } \\
\text { of controls }\end{array}$ & $\begin{array}{c}\text { No. of } \\
\text { controls }\end{array}$ & $\begin{array}{l}\text { Main phenotype } \\
\text { of cases }\end{array}$ & $\begin{array}{c}\text { No. of } \\
\text { cases }\end{array}$ & $\begin{array}{l}\text { Method of } \\
\text { measure }\end{array}$ & Ratio & $P$ value & Ref. \\
\hline$L E P$ & Obesity & USA & Canonical & Subcutaneous fat & $\begin{array}{l}\text { Lean controls (BMI }<27 / \mathrm{kg} / \\
\mathrm{m}^{2} \text { for females and }<27.3 / \\
\mathrm{kg} / \mathrm{m}^{2} \text { for males) without } \\
\text { diabetes }\end{array}$ & 27 & Obese individuals without diabetes & 27 & Quantitative RT-PCR & 1,54 & $3.81 \mathrm{E}-04$ & 131 \\
\hline$L E P$ & Obesity & Austia & Canonical & Subcutaneous fat & $\begin{array}{l}\text { Lean controls without major } \\
\text { illness }\end{array}$ & 19 & Obese individuals (BMI $>30 \mathrm{~kg} / \mathrm{m}^{2}$ ) & 89 & Quantitative RT-PCR & 2,08 & 4.13E-04 & 128 \\
\hline$L E P$ & Obesity & Sweden & Canonical & Subcutaneous fat & $\begin{array}{r}\text { Lean women }(\mathrm{BMI}<27 \mathrm{~kg} / \\
\left.\mathrm{m}^{2}\right) \text { with no major illness }\end{array}$ & 11 & $\begin{array}{l}\text { Obese women }\left(\mathrm{BMI}>30 \mathrm{~kg} / \mathrm{m}^{2}\right) \text { with } \\
\text { no major illness }\end{array}$ & 20 & $\begin{array}{l}\text { Quantitative Northern- } \\
\text { blot }\end{array}$ & 2,54 & $3.58 \mathrm{E}-05$ & 132 \\
\hline$L E P$ & Obesity & $\begin{array}{l}\text { United } \\
\text { Kingdom }\end{array}$ & Canonical & Subcutaneous fat & $\begin{array}{l}\text { Lean controls }(\mathrm{BMI}<25 \mathrm{~kg} / \\
\left.\mathrm{m}^{2}\right) \text { without diabetes }\end{array}$ & 14 & $\begin{array}{l}\text { Obese or overweight individuals (BMI > } \\
27 / \mathrm{kg} / \mathrm{m}^{2} \text { ) without diabetes }\end{array}$ & 9 & In-situ hybridization & 1,98 & $1.52 \mathrm{E}-02$ & 129 \\
\hline$L E P$ & Obesity & France & Canonical & Subcutaneous fat & $\begin{array}{l}\text { Lean controls }(\mathrm{BMI}<25 \mathrm{~kg} / \\
\left.\mathrm{m}^{2}\right)\end{array}$ & 12 & Obese individuals (BMI $30>\mathrm{kg} / \mathrm{m}^{2}$ ) & 7 & Quantitative RT-PCR & 7,70 & $2.63 \mathrm{E}-07$ & 133 \\
\hline$L E P$ & Obesity & China & Canonical & Subcutaneous fat & $\begin{array}{l}\text { Lean controls }(\mathrm{BMI}<24 \mathrm{~kg} / \\
\left.\mathrm{m}^{2}\right)\end{array}$ & 11 & $\begin{array}{l}\text { Obese or overweight individuals (BMI > } \\
27 \mathrm{~kg} / \mathrm{m}^{2} \text { ) without diabetes }\end{array}$ & 12 & Quantitative RT-PCR & 1,78 & $2.78 \mathrm{E}-03$ & 134 \\
\hline PPARG & Diabetes type 2 & France & $\begin{array}{l}\text { PPARG } \\
\quad \text { isoform } 1\end{array}$ & Subcutaneous fat & Lean non-diabetic individuals & 10 & Diabetics type 2 & 9 & Dot-blot & 1,32 & $2.12 \mathrm{E}-01$ & 135 \\
\hline PPARG & Diabetes type 2 & France & $\begin{array}{l}\text { PPARG } \\
\quad \text { isoform } 1\end{array}$ & Subcutaneous fat & Obese non-diabetic individuals & 10 & Diabetics type 2 & 9 & Competitive RT-PCR & 1,12 & $5.10 \mathrm{E}-01$ & 135 \\
\hline PPARG & Diabetes type 2 & France & $\begin{array}{l}\text { PPARG } \\
\quad \text { isoform } 2\end{array}$ & Subcutaneous fat & Lean non-diabetic individuals & 10 & Diabetics type 2 & 9 & Competitive RT-PCR & 0,69 & $2.80 \mathrm{E}-02$ & 135 \\
\hline PPARG & Diabetes type 2 & France & $\begin{array}{l}\text { PPARG } \\
\quad \text { isoform } 2\end{array}$ & Subcutaneous fat & Obese non-diabetic individuals & 10 & Diabetics type 2 & 9 & Competitive RT-PCR & 0,92 & $6.03 \mathrm{E}-01$ & 135 \\
\hline$P P A R G$ & Diabetes type 2 & USA & Canonical & Skeletal muscle & $\begin{array}{l}\text { Lean controls }(\mathrm{BMI}<27 \mathrm{~kg} / \\
\left.\mathrm{m}^{2}\right) \text { without diabetes }\end{array}$ & 7 & Diabetics type 2 & 7 & Competitive RT-PCR & 1,41 & $1.89 \mathrm{E}-01$ & 136 \\
\hline PPARG & Diabetes type 2 & USA & Canonical & Skeletal muscle & $\begin{array}{l}\text { Obese individuals without } \\
\text { diabetes }\end{array}$ & 6 & Diabetics type 2 & 7 & RNase protection assay & 1,12 & $7.45 \mathrm{E}-01$ & 136 \\
\hline PPARG & Diabetes type 2 & USA & Canonical & Skeletal muscle & $\begin{array}{l}\text { Lean controls }(\mathrm{BMI}<27 \mathrm{~kg} / \\
\left.\mathrm{m}^{2}\right) \text { with no diabetes }\end{array}$ & 6 & Diabetics type 2 & 5 & RNase protection assay & 2,98 & $4.20 \mathrm{E}-05$ & 137 \\
\hline PPARG & Diabetes type 2 & USA & Canonical & Skeletal muscle & $\begin{array}{l}\text { Obese individuals }(\mathrm{BMI}>30 \\
\mathrm{kg} / \mathrm{m}^{2} \text { ) with normal glucose } \\
\text { tolerance }\end{array}$ & 5 & Diabetics type 2 & 5 & Competitive RT-PCR & 1,20 & $1.84 \mathrm{E}-01$ & 137 \\
\hline PPARG & Obesity & Austia & Canonical & Omental fat & $\begin{array}{l}\text { Lean controls without major } \\
\text { illness }\end{array}$ & 20 & Obese individuals $\left(\mathrm{BMI}>30 \mathrm{~kg} / \mathrm{m}^{2}\right)$ & 76 & Competitive RT-PCR & 0,97 & $7.98 \mathrm{E}-01$ & 128 \\
\hline PPARG & Obesity & USA & Canonical & Skeletal muscle & $\begin{array}{l}\text { Lean controls }(\mathrm{BMI}<27 \mathrm{~kg} / \\
\left.\mathrm{m}^{2}\right) \text { without diabetes }\end{array}$ & 7 & Obese individuals without diabetes & 6 & $\begin{array}{l}\text { Quantitative Northern- } \\
\text { blot }\end{array}$ & 1,27 & $5.12 \mathrm{E}-01$ & 136 \\
\hline PPARG & Obesity & USA & Canonical & Skeletal muscle & $\begin{array}{l}\text { Lean controls }(\mathrm{BMI}<27 \mathrm{~kg} / \\
\left.\mathrm{m}^{2}\right) \text { with no diabetes }\end{array}$ & 6 & $\begin{array}{l}\text { Obese inviduals }\left(\mathrm{BMI}>30 \mathrm{~kg} / \mathrm{m}^{2}\right) \text { with } \\
\text { normal glucose tolerance }\end{array}$ & 5 & RNase protection assay & 2,49 & $6.04 \mathrm{E}-05$ & 137 \\
\hline PPARG & Obesity & France & $\begin{array}{l}\text { PPARG } \\
\quad \text { isoform } 1\end{array}$ & Subcutaneous fat & Lean non-diabetic individuals & 10 & Obese non-diabetic individuals & 10 & Competitive RT-PCR & 1,18 & $4.31 \mathrm{E}-01$ & 135 \\
\hline PPARG & Obesity & France & $\begin{array}{l}\text { PPARG } \\
\quad \text { isoform } 2\end{array}$ & Subcutaneous fat & Lean non-diabetic individuals & 10 & Obese non-diabetic individuals & 10 & Competitive RT-PCR & 0,75 & $1.13 \mathrm{E}-01$ & 135 \\
\hline PPARG & Obesity & France & $\begin{array}{l}\text { PPARG } \\
\quad \text { isoform } 1\end{array}$ & Subcutaneous fat & Lean non-diabetic individuals & 5 & Obese non-diabetic individuals & 5 & Competitive RT-PCR & 1,37 & $2.95 \mathrm{E}-01$ & 135 \\
\hline PPARG & Obesity & France & $\begin{array}{l}\text { PPARG } \\
\quad \text { isoform } 2\end{array}$ & Subcutaneous fat & Lean non-diabetic individuals & 5 & Obese non-diabetic individuals & 5 & Competitive RT-PCR & 0,88 & $6.42 \mathrm{E}-01$ & 135 \\
\hline PPARG & Obesity & Austia & Canonical & Subcutaneous fat & $\begin{array}{l}\text { Lean controls without major } \\
\text { illness }\end{array}$ & 19 & Obese individuals $\left(\mathrm{BMI}>30 \mathrm{~kg} / \mathrm{m}^{2}\right)$ & 50 & Competitive RT-PCR & 1,01 & $9.32 \mathrm{E}-01$ & 128 \\
\hline PPARG & Obesity & USA & $\begin{array}{l}\text { PPARG } \\
\quad \text { isoform } 1\end{array}$ & Subcutaneous fat & $\begin{array}{l}\text { Lean individuals }(\mathrm{BMI}<25 \\
\left.\mathrm{kg} / \mathrm{m}^{2}\right) \text { without diabetes or } \\
\text { malignancies }\end{array}$ & 11 & $\begin{array}{l}\text { Obese or overweight individuals (BMI > } \\
27 \mathrm{~kg} / \mathrm{m}^{2} \text { ) without diabetes or } \\
\text { malignancies }\end{array}$ & 11 & Competitive RT-PCR & 0,30 & $4.25 \mathrm{E}-03$ & 138 \\
\hline PPARG & Obesity & USA & $\begin{array}{l}\text { PPARG } \\
\quad \text { isoform } 2\end{array}$ & Subcutaneous fat & $\begin{array}{l}\text { Lean individuals }(\mathrm{BMI}<25 \\
\left.\mathrm{kg} / \mathrm{m}^{2}\right) \text { without diabetes or } \\
\text { malignancies }\end{array}$ & 11 & $\begin{array}{l}\text { Obese or overweight individuals (BMI > } \\
27 \mathrm{~kg} / \mathrm{m}^{2} \text { ) without diabetes or } \\
\text { malignancies }\end{array}$ & 11 & Competitive RT-PCR & 1,55 & $4.66 \mathrm{E}-02$ & 138 \\
\hline PPARG & Obesity & USA & $\begin{array}{l}\text { PPARG } \\
\text { isoform } 2\end{array}$ & Subcutaneous fat & Lean $\left(\mathrm{BMI}<25 \mathrm{~kg} / \mathrm{m}^{2}\right)$ & 14 & Morbid obesity & 24 & Competitive RT-PCR & 0,65 & $2.45 \mathrm{E}-05$ & 139 \\
\hline PSEN1 & $\begin{array}{l}\text { Alzheimer's } \\
\text { disease }\end{array}$ & Sweden & Canonical & Brain, frontal cortex & $\begin{array}{l}\text { Controls affected or not with } \\
\text { non-Alzheimer neurological } \\
\text { diseases }\end{array}$ & 9 & $\begin{array}{l}\text { Individuals with Alzheimer disease with } \\
\text { neuropathological changes }\end{array}$ & 14 & Competitive RT-PCR & 0,99 & $9.18 \mathrm{E}-01$ & 140 \\
\hline PSEN1 & $\begin{array}{l}\text { Alzheimer's } \\
\text { disease }\end{array}$ & Japan & Canonical & Skin fibroblasts & $\begin{array}{l}\text { Controls with neurological } \\
\text { disease without dementia }\end{array}$ & 10 & $\begin{array}{l}\text { Individuals with Alzheimer disease } \\
\text { according to DSM-IIIR criteria }\end{array}$ & 18 & $\begin{array}{l}\text { Quantitative Northern- } \\
\text { blot }\end{array}$ & 2,25 & $3.32 \mathrm{E}-02$ & 141 \\
\hline
\end{tabular}


Altered gene expression in human susceptibility genes

Table 2

(Continued)

\begin{tabular}{|c|c|c|c|c|c|c|c|c|c|c|c|c|}
\hline Gene & Disease/trait & Country & $\begin{array}{l}\text { mRNA } \\
\text { isoform }\end{array}$ & Tissue & $\begin{array}{l}\text { Main phenotype } \\
\text { of controls }\end{array}$ & $\begin{array}{l}\text { No. of } \\
\text { controls }\end{array}$ & $\begin{array}{l}\text { Main phenotype } \\
\text { of cases }\end{array}$ & $\begin{array}{c}\text { No. of } \\
\text { cases }\end{array}$ & $\begin{array}{l}\text { Method of } \\
\text { measure }\end{array}$ & Ratio & $P$ value & Ref. \\
\hline PSEN1 & $\begin{array}{l}\text { Alzheimer's } \\
\text { disease }\end{array}$ & Japan & Canonical & $\begin{array}{l}\text { Brain, temporal } \\
\quad \text { cortex }\end{array}$ & $\begin{array}{l}\text { Controls with neurological } \\
\text { disease with no dementia }\end{array}$ & 23 & $\begin{array}{l}\text { Individuals with Alzheimer disease with } \\
\text { neuropathological changes }\end{array}$ & 17 & Real-time RT-PCR & 1,94 & $6.09 \mathrm{E}-05$ & 142 \\
\hline PSEN1 & $\begin{array}{l}\text { Alzheimer's } \\
\text { disease }\end{array}$ & Sweden & Canonical & $\begin{array}{l}\text { Brain, temporal } \\
\quad \text { cortex }\end{array}$ & $\begin{array}{l}\text { Controls affected or not with } \\
\text { non-Alzheimer neurological } \\
\text { diseases }\end{array}$ & 8 & $\begin{array}{l}\text { Individuals with Alzheimer disease with } \\
\text { neuropathological changes }\end{array}$ & 14 & RNase protection assay & 0,88 & 4.42E-01 & 140 \\
\hline SERPINA 8 & $\mathrm{CAD} / \mathrm{MI}$ & Italy & Canonical & $\begin{array}{l}\text { Heart, left } \\
\text { ventricular wall }\end{array}$ & $\begin{array}{l}\text { Controls with normal } \\
\text { coronarography }\end{array}$ & 21 & Individuals with stable angina & 32 & RNase protection assay & 0,92 & $6.70 \mathrm{E}-01$ & 101 \\
\hline SERPINA 8 & $\mathrm{CAD} / \mathrm{MI}$ & Italy & Canonical & $\begin{array}{l}\text { Heart, left } \\
\text { ventricular wall }\end{array}$ & $\begin{array}{l}\text { Controls with normal } \\
\text { coronarography }\end{array}$ & 21 & Individuals with unstable angina & 35 & In-situ hybridization & 1,88 & $9.70 \mathrm{E}-08$ & 101 \\
\hline SERPINA 8 & Hypertension & Australia & Canonical & Subcutaneous fat & $\begin{array}{l}\text { Controls with normal tension } \\
\text { and no family history }\end{array}$ & 6 & $\begin{array}{l}\text { Individuals with isolated systolic } \\
\text { hypertension }\end{array}$ & 8 & No data & 0,12 & $1.20 \mathrm{E}-01$ & 143 \\
\hline SLC6A4 & Bipolar disorder & USA & Canonical & Brain, frontal cortex & $\begin{array}{l}\text { Controls with no psychiatric } \\
\text { disorder (no details) }\end{array}$ & 15 & $\begin{array}{l}\text { Bipolar disorder according to DSM-IV } \\
\text { criteria }\end{array}$ & 19 & No data & 4,57 & $2,16 \mathrm{E}-10$ & 144 \\
\hline$T N F$ & Diabetes type 2 & Germany & Canonical & Subcutaneous fat & Lean, no diabetes & 12 & $\begin{array}{l}\text { Diabetics type } 2 \text { or individuals with } \\
\text { impaired glucose tolerance }\end{array}$ & 10 & In-situ hybridization & 2,36 & $3.99 \mathrm{E}-02$ & 145 \\
\hline TNF & Diabetes type 2 & Germany & Canonical & Subcutaneous fat & $\begin{array}{l}\text { Obese individuals with normal } \\
\text { glucose tolerance }\end{array}$ & 18 & $\begin{array}{l}\text { Diabetic type } 2 \text { or individuals with } \\
\text { impaired glucose tolerance }\end{array}$ & 10 & $\begin{array}{l}\text { Quantitative Northern- } \\
\text { blot }\end{array}$ & 1,57 & $8.82 \mathrm{E}-02$ & 145 \\
\hline$T N F$ & Obesity & USA & Canonical & Subcutaneous fat & Lean controls with no diabetes & 6 & Obese individuals & 9 & Quantitative RT-PCR & 2,60 & $1.11 \mathrm{E}-03$ & 146 \\
\hline$T N F$ & Obesity & Germany & Canonical & Subcutaneous fat & Lean, no diabetes & 12 & $\begin{array}{l}\text { Obese individuals with normal glucose } \\
\text { tolerance }\end{array}$ & 18 & No data & 1,50 & $2.32 \mathrm{E}-02$ & 145 \\
\hline$T N F$ & Obesity & USA & Canonical & Subcutaneous fat & $\begin{array}{l}\text { Lean controls }(\mathrm{BMI}<25 / \mathrm{kg} / \\
\left.\mathrm{m}^{2}\right)\end{array}$ & 8 & $\begin{array}{l}\text { Obese or overweight individuals (BMI > } \\
27 \mathrm{~kg} / \mathrm{m}^{2} \text { ) }\end{array}$ & 31 & No data & 1,66 & $1.59 \mathrm{E}-01$ & 147 \\
\hline TNF & Obesity & USA & Canonical & Subcutaneous fat & $\begin{array}{l}\text { Lean controls }(\mathrm{BMI}<25 \mathrm{~kg} / \\
\left.\mathrm{m}^{2}\right)\end{array}$ & 9 & $\begin{array}{l}\text { Obese or overweight individuals (BMI > } \\
25 \mathrm{~kg} / \mathrm{m}^{2} \text { ) }\end{array}$ & 41 & In-situ hybridization & 2,15 & 4.81E-05 & 148 \\
\hline$T N F$ & Obesity & Finland & Canonical & Subcutaneous fat & $\begin{array}{l}\text { Lean individuals without } \\
\text { diabetes }\end{array}$ & 20 & $\begin{array}{l}\text { Obese or morbid obese individuals (BMI } \\
>30 \mathrm{~kg} / \mathrm{m}^{2} \text { ) without diabetes }\end{array}$ & 61 & No data & 1,39 & $4.80 \mathrm{E}-02$ & 149 \\
\hline$U C P 1$ & Obesity & Austia & Canonical & Omental fat & Lean controls (no details) & 14 & Obese individuals (no details) & 78 & Quantitative RT-PCR & 0,50 & $5.83 \mathrm{E}-05$ & 150 \\
\hline$U C P 1$ & Obesity & Austia & Canonical & Subcutaneous fat & Lean controls (no details) & 10 & Obese individuals (no details) & 23 & No data & 1,22 & $5.02 \mathrm{E}-01$ & 150 \\
\hline UCP2 & Obesity & Austia & Canonical & Omental fat & $\begin{array}{l}\text { Lean controls }(\mathrm{BMI}<27 \mathrm{~kg} / \\
\left.\mathrm{m}^{2}\right)\end{array}$ & 28 & Obese individuals (BMI $>30 \mathrm{~kg} / \mathrm{m}^{2}$ ) & 95 & No data & 0,67 & $4.92 \mathrm{E}-08$ & 151 \\
\hline UCP2 & Obesity & France & Canonical & Skeletal muscle & Lean controls & 6 & Obese individuals & 5 & Competitive RT-PCR & 1,24 & $5.29 \mathrm{E}-01$ & 152 \\
\hline UCP2 & Obesity & France & Canonical & Skeletal muscle & Lean controls & 6 & Obese individuals & 6 & Competitive RT-PCR & 0,98 & $9.32 \mathrm{E}-01$ & 152 \\
\hline UCP2 & Obesity & Sweden & Canonical & Skeletal muscle & Lean controls without diabetes & 6 & Obese individuals free of drug therapy & 6 & Competitive RT-PCR & 0,72 & $1.04 \mathrm{E}-03$ & 153 \\
\hline UCP2 & Obesity & Spain & Canonical & Skeletal muscle & Lean controls without diabetes & 10 & $\begin{array}{l}\text { Obese individuals }\left(\mathrm{BMI}>30 \mathrm{~kg} / \mathrm{m}^{2}\right) \\
\text { with normal glucose tolerance }\end{array}$ & 14 & Competitive RT-PCR & 0,97 & $8.49 \mathrm{E}-01$ & 154 \\
\hline UCP2 & Obesity & USA & Canonical & Skeletal muscle & $\begin{array}{l}\text { Lean controls }(\mathrm{BMI}<27 \mathrm{~kg} / \\
\left.\mathrm{m}^{2}\right)\end{array}$ & 14 & Obese individuals (BMI $>27 \mathrm{~kg} / \mathrm{m}^{2}$ ) & 16 & No data & 0,93 & $5.63 \mathrm{E}-01$ & 155 \\
\hline UCP2 & Obesity & France & Canonical & Subcutaneous fat & Lean controls & 6 & Obese individuals & 6 & No data & 1,46 & $2.52 \mathrm{E}-01$ & 152 \\
\hline UCP2 & Obesity & France & Canonical & Subcutaneous fat & Lean controls & 5 & Obese individuals & 5 & Competitive RT-PCR & 1,31 & $2.84 \mathrm{E}-01$ & 152 \\
\hline UCP2 & Obesity & Austia & Canonical & Subcutaneous fat & $\begin{array}{l}\text { Lean controls }(\mathrm{BMI}<27 \mathrm{~kg} / \\
\left.\mathrm{m}^{2}\right)\end{array}$ & 19 & Obese individuals (BMI $>30 \mathrm{~kg} / \mathrm{m}^{2}$ ) & 82 & Competitive RT-PCR & 0,92 & $2.76 \mathrm{E}-01$ & 151 \\
\hline UCP2 & Obesity & USA & Canonical & Subcutaneous fat & $\begin{array}{l}\text { Lean controls }(\mathrm{BMI}<27 \mathrm{~kg} / \\
\left.\mathrm{m}^{2}\right)\end{array}$ & 17 & Obese individuals $\left(\mathrm{BMI}>27 \mathrm{~kg} / \mathrm{m}^{2}\right)$ & 17 & Competitive RT-PCR & 0,93 & 7.13E-01 & 155 \\
\hline UCP3 & Obesity & Austia & $\begin{array}{l}\text { UCP3 long } \\
\text { isoform }\end{array}$ & Skeletal muscle & Lean controls, no diabetes & 15 & $\begin{array}{l}\text { Morbid obesity treated by gastric } \\
\text { banding, no diabetes }\end{array}$ & 38 & Competitive RT-PCR & 1,32 & $3.39 \mathrm{E}-02$ & 156 \\
\hline UCP3 & Obesity & Austia & $\begin{array}{l}\text { UCP3 short } \\
\text { isoform }\end{array}$ & Skeletal muscle & Lean controls, no diabetes & 15 & $\begin{array}{l}\text { Morbid obesity treated by gastric } \\
\text { banding, no diabetes }\end{array}$ & 38 & Competitive RT-PCR & 1,31 & $6.61 \mathrm{E}-02$ & 156 \\
\hline UCP3 & Obesity & France & $\begin{array}{l}\text { UCP3 short } \\
\text { isoform }\end{array}$ & Skeletal muscle & Lean controls without diabetes & 9 & Obese individuals without diabetes & 7 & In-situ hybridization & 0,73 & 4.62E-01 & 157 \\
\hline UCP3 & Obesity & France & $\begin{array}{l}\text { UCP3 long } \\
\text { isoform }\end{array}$ & Skeletal muscle & Lean controls without diabetes & 9 & Obese individuals without diabetes & 7 & Competitive RT-PCR & 1,10 & 8.09E-01 & 157 \\
\hline UCP3 & Obesity & Sweden & Canonical & Skeletal muscle & Lean controls without diabetes & 6 & Obese individuals free of drug therapy & 6 & RNase protection assay & 1,02 & $8.21 \mathrm{E}-01$ & 153 \\
\hline UCP3 & Obesity & USA & $\begin{array}{l}\text { UCP3 long } \\
\text { isoform }\end{array}$ & Skeletal muscle & $\begin{array}{l}\text { Lean controls }(\mathrm{BMI}<27 \mathrm{~kg} / \\
\left.\mathrm{m}^{2}\right)\end{array}$ & 14 & Obese individuals $\left(\mathrm{BMI}>27 \mathrm{~kg} / \mathrm{m}^{2}\right.$ ) & 16 & Competitive RT-PCR & 1,15 & $3.54 \mathrm{E}-01$ & 155 \\
\hline UCP3 & Obesity & USA & $\begin{array}{l}\text { UCP3 short } \\
\text { isoform }\end{array}$ & Skeletal muscle & $\begin{array}{l}\text { Lean controls }(\mathrm{BMI}<27 \mathrm{~kg} / \\
\left.\mathrm{m}^{2}\right)\end{array}$ & 14 & Obese individuals $\left(\mathrm{BMI}>27 \mathrm{~kg} / \mathrm{m}^{2}\right.$ ) & 16 & Competitive RT-PCR & 1,08 & $5.95 \mathrm{E}-01$ & 155 \\
\hline UCP3 & Obesity & France & Canonical & Skeletal muscle & Lean controls & 5 & Obese individuals & 5 & Competitive RT-PCR & 1,42 & $1.86 \mathrm{E}-01$ & 152 \\
\hline
\end{tabular}


Table 2

(Continued)

\begin{tabular}{|c|c|c|c|c|c|c|c|c|c|c|c|c|}
\hline Gene & Disease/trait & Country & $\begin{array}{l}\text { mRNA } \\
\text { isoform }\end{array}$ & Tissue & $\begin{array}{l}\text { Main phenotype } \\
\text { of controls }\end{array}$ & $\begin{array}{l}\text { No. of } \\
\text { controls }\end{array}$ & $\begin{array}{l}\text { Main phenotype } \\
\text { of cases }\end{array}$ & $\begin{array}{l}\text { No. of } \\
\text { cases }\end{array}$ & $\begin{array}{l}\text { Method of } \\
\text { measure }\end{array}$ & Ratio & $P$ value & Ref. \\
\hline$U C P 3$ & Obesity & France & Canonical & Skeletal muscle & Lean controls & 8 & Obese individuals & 6 & RNase protection assay & 0,74 & $2.29 \mathrm{E}-01$ & 152 \\
\hline$U C P 3$ & Obesity & Spain & Canonical & Skeletal muscle & Lean controls without diabetes & 10 & $\begin{array}{l}\text { Obese individuals }\left(\mathrm{BMI}>30 \mathrm{~kg} / \mathrm{m}^{2} \text { ) }\right. \\
\text { with normal glucose tolerance }\end{array}$ & 14 & RNase protection assay & 1,06 & $7.75 \mathrm{E}-01$ & 154 \\
\hline$U C P 3$ & Obesity & Austia & $\begin{array}{l}\text { UCP3 short } \\
\text { isoform }\end{array}$ & Skeletal muscle & Lean controls, no diabetes & 15 & $\begin{array}{l}\text { Morbid obesity treated by gastric } \\
\text { banding, no diabetes }\end{array}$ & 38 & RNase protection assay & 1,31 & $6.61 \mathrm{E}-02$ & 156 \\
\hline$U C P 3$ & Obesity & France & $\begin{array}{l}\text { UCP3 short } \\
\text { isoform }\end{array}$ & Skeletal muscle & Lean controls without diabetes & 9 & Obese individuals without diabetes & 7 & Competitive RT-PCR & 0,73 & 4.62E-01 & 157 \\
\hline UCP3 & Obesity & France & $\begin{array}{l}\text { UCP3 long } \\
\text { isoform }\end{array}$ & Skeletal muscle & Lean controls without diabetes & 9 & Obese individuals without diabetes & 7 & Competitive RT-PCR & 1,10 & $8.09 \mathrm{E}-01$ & 157 \\
\hline UCP3 & Obesity & Sweden & Canonical & Skeletal muscle & Lean controls without diabetes & 6 & Obese individuals free of drug therapy & 6 & In-situ hybridization & 1,02 & $8.21 \mathrm{E}-01$ & 153 \\
\hline$U C P 3$ & Obesity & USA & $\begin{array}{l}\text { UCP3 long } \\
\text { isoform }\end{array}$ & Skeletal muscle & $\begin{array}{l}\text { Lean controls }(\mathrm{BMI}<27 \mathrm{~kg} / \\
\left.\mathrm{m}^{2}\right)\end{array}$ & 14 & Obese individuals $\left(\mathrm{BMI}>27 \mathrm{~kg} / \mathrm{m}^{2}\right.$ ) & 16 & RNase protection assay & 1,15 & $3.54 \mathrm{E}-01$ & 155 \\
\hline$U C P 3$ & Obesity & USA & $\begin{array}{l}\text { UCP3 short } \\
\text { isoform }\end{array}$ & Skeletal muscle & $\begin{array}{l}\text { Lean controls }(\mathrm{BMI}<27 \mathrm{~kg} / \\
\left.\mathrm{m}^{2}\right)\end{array}$ & 14 & Obese individuals $\left(\mathrm{BMI}>27 \mathrm{~kg} / \mathrm{m}^{2}\right.$ ) & 16 & RNase protection assay & 1,08 & $5.95 \mathrm{E}-01$ & 155 \\
\hline UCP3 & Obesity & France & Canonical & Skeletal muscle & Lean controls & 5 & Obese individuals & 5 & Competitive RT-PCR & 1,42 & $1.86 \mathrm{E}-01$ & 152 \\
\hline
\end{tabular}

toward positive results could explain such difference. However, the number published and unpublished nonsignificant studies required to account for these results should be at least 19-fold higher than the number of significant studies, i.e., 1140 studies (95\% CI: 851-1428). Because there were only 60 nonsignificant published studies, one must postulate the existence of 1080 unpublished negative studies (95\% CI: 791-1368), which appear frankly unrealistic. The ratio of statistically significant gene expression studies was similar between the genes also known to be involved in Mendelian-inherited disorders or not $\left(27\right.$ out of 58 vs. 31 out of $62 ; \chi^{2}$-test, 1 degree of freedom: $0.4 ; P=0.46)$. The ratio of statistically significant gene expression studies was also similar for the gene-disease associations tested by association before expression studies or after ( 20 out of 33 vs. 40 out of $87 ; \chi^{2}$-test, 1 degree of freedom: $1.3 ; P=$ $0.15)$. Furthermore, out of the 60 studies leading to statistically significant results, 15 were first reports and 45 were replications of previous studies. Thirty-four of these replications reports showed statistically significant difference in expression in agreement with the original report, whereas only 11 showed a statistically significant change in transcript levels but in the opposite direction to that described in the first report. These figures are significantly different from the 22.5 studies expected to occur randomly in the same and opposite direction (95\% CI: $19.0-26.0 ; \chi^{2}$-test, 1 degree of freedom: $11.7 ; P=$ $\left.6 \times 10^{-4}\right)$.

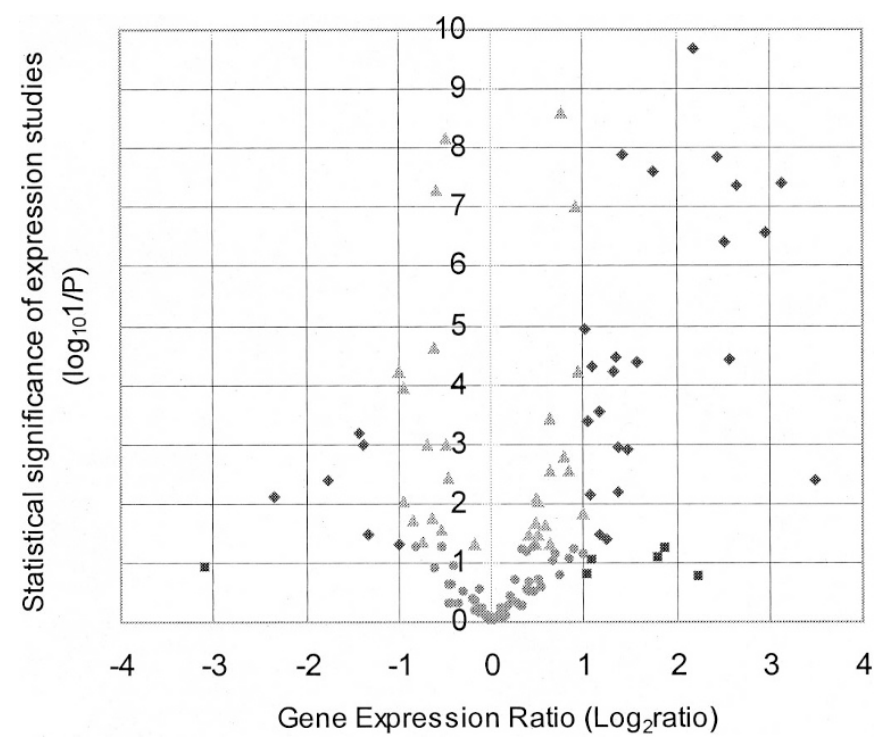

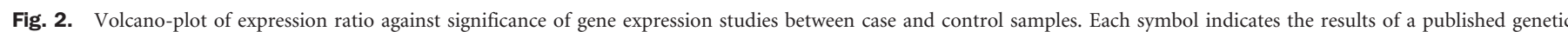

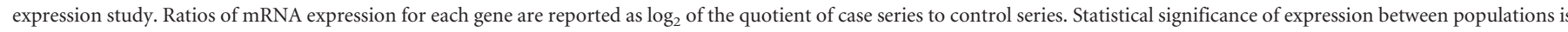

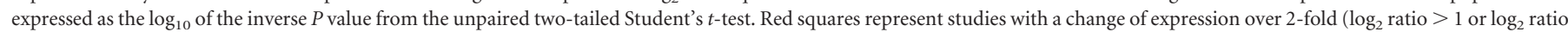

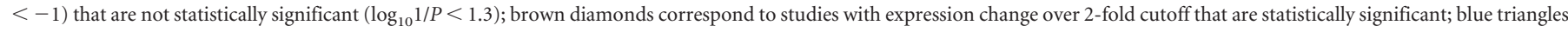
indicate studies with changes under 2-fold that are statistically significant; and green circles indicate studies with changes under 2 -fold that are not statistically significant. 
Table 3

Univariate ANOVA analysis for the effect of various parameters on gene expression change

\begin{tabular}{lcccc}
\hline Source & $\begin{array}{c}\text { Type III Sum } \\
\text { of Squares }\end{array}$ & df & Mean Square & F-statistics \\
\hline Gene-disease association & 5,42 & 20 & 0,27 & 2,36 \\
Tissue analyzed & 1,70 & 7 & 0,24 & 2,15 \\
Method for expression analysis & 1,68 & 8 & 0,21 & 0.003 \\
Intercept & 5,42 & 20 & 0,27 & 0.05 \\
Residual & 9,52 & 83 & 0,11 & 0.08 \\
Total & 35 & 120 & & 0.0003 \\
Corrected Total & 24,79 & 119 & & \\
\hline
\end{tabular}

Several sources of bias, related to the heterogeneity of the expression studies presently analyzed, can impact the results of the present meta-analysis. For instance, some susceptibility genes have been tested by allelic association after gene expression analysis, while others were tested before. Although this was not found to impact the results of the present analysis, the frequency of gene expression changes could be overestimated in the subset of genes initially tested for gene expression. Furthermore, the present results could be altered by the fact that some results of gene expression were not independent one from the other, as several samples or genes were analyzed in the same studies. To test this hypothesis, the subset of 27 strictly independent gene expression studies was individually reanalyzed. Positive results were still obtained, as 24 out of the 27 gene expression studies were statistically significant (89\%) exceeding the number of 1.35 predicted by chance $\left(P=10^{-28}\right.$, binomial distribution). In summary, although the strength of the present statistical analysis supports the validity of the present findings, they should be taken cautiously and require further confirmation.

Actually, the method based on comparing the expression level between series of cases and controls for human susceptibility genes shows a major limitation: only $36(60.0 \%)$ and 19 (31.7\%) out of the 60 statistically significant gene expression studies reached 2- or 3-fold changes in expression level, respectively (Fig. 2). In contrast, only $6(10 \%)$ and $3(5.0 \%)$ out of the 60 non-statistically significant studies reach these respective thresholds. Therefore, 2- or 3-fold change expression thresholds have in the present study a sensitivity of $50 \%$ and $23.5 \%$, respectively. Consequently, the reliability of testing difference in mRNA abundance can be seriously impacted by the weak differences in transcript abundance between cases and controls.

To test the impact of various methodological parameters on gene expression change, I next performed a univariate ANOVA analysis (Table 3$)$. The gene $(P=0.003)$ and the nature of tissue analyzed $(P=0.05)$ were associated with gene expression change between cases and controls, whereas the method of assay to measure transcript abundance had no significant effect $(P=0.08)$. Multivariate analysis by logistic regression model with a forward stepwise search was performed to assess the relative influence of the univariate factors on gene expression ratio. Both two previous factors were found to be independently associated with gene expression ratio, the gene having a strongest effect $(P=0.002)$, while the type of tissue used for expression analysis was more weakly associated $(P=$ 0.01 ). Therefore, because of the influence of the gene itself and the tissue analyzed, the reliability of differential expression analysis is expected to vary strongly from one gene or one tissue to another.

Taken together, the present results demonstrate significant differences in transcript levels between normal and pathologic tissues of human susceptibility genes. These results rationalize the use of comparative gene expression analysis for gene discovery studies. However, differences in transcript amounts appear much lower than those typically found between inbred environmentally controlled animal models. ${ }^{6,7}$ These weak differences should be taken into account for the design of gene susceptibility studies using differences of transcript amounts as a tool ${ }^{7-49}$ for gene ${ }^{50-99}$ discovery/validation. ${ }^{100-157}$

\section{ACKNOWLEDGMENTS}

I thank Jean Frézal (GenAtlas, Paris, Fance) for providing comprehensive details of the genes involved in human Mendelian-inherited disorders, Joel Hirschhorn (Massachusetts Institute of Technology, Boston, MA) for additional information on its meta-analysis, and Laurent Essioux (Hauffman-LaRoche Laboratories, Department of Biostatistics, Basel, Switzerland) for helpful discussions. I also thank three anonymous reviewers for helpful comments on this manuscript.

\section{References}

1. Segal JA, Barnett JL, Crawford DL. Functional analyses of natural variation in Sp1 binding sites of a TATA-less promoter. J Mol Evol 1999;49:736-749.

2. Crawford DL, Segal JA, Barnett JL. Evolutionary analysis of TATA-less proximal promoter function. Mol Biol Evol 1999;16:194-207.

3. Lewis BP, Green RE, Brenner SE. Evidence for the widespread coupling of alternative splicing and nonsense-mediated mRNA decay in humans. Proc Natl Acad Sci USA 2003;100:189-192.

4. Stephens JC, Schneider JA, Tanguay DA et al. Haplotype variation and linkage disequilibrium in 313 human genes. Science 2001;293:489-493.

5. Schadt EE, Monks SA, Drake TA et al. Genetics of gene expression surveyed in maize, mouse and man. Nature 2003;422:297-302.

6. Korstanje R, Paigen B. From QTL to gene: The harvest begins. Nat Genet 2002;31: 235-236. 
7. Karp CL, Grupe A, Schadt E et al. Identification of complement factor 5 as a susceptibility locus for experimental allergic asthma. Nat Immunol 2000;1:221-226.

8. Hirschhorn JN, Lohmueller K, Byrne E, Hirschhorn K. A comprehensive review of genetic association studies. Genet Med 2002;4:45-61.

9. Lohmueller KE, Pearce CL, Pike M, Lander ES, Hirschhorn JN. Meta-analysis of genetic association studies supports a contribution of common variants to susceptibility to common disease. Nat Genet 2003;33:177-182.

10. Blacker D, Wilcox MA, Laird NM et al. Alpha-2 macroglobulin is genetically associated with Alzheimer disease. Nat Genet 1998;19:357-360.

11. Inoue $\mathrm{H}$, Ferrer J, Welling $\mathrm{CM}$ et al. Sequence variants in the sulfonylurea receptor (SUR) gene are associated with NIDDM in Caucasians. Diabetes 1996;45:825-831.

12. Cambien F, Poirier O, Lecerf L et al. Deletion polymorphism in the gene for angiotensin-converting enzyme is a potent risk factor for myocardial infarction. $\mathrm{Na}$ ture 1992;359:641-644.

13. Zee RY, Lou YK, Griffiths LR, Morris BJ. Association of a polymorphism of the angiotensin I-converting enzyme gene with essential hypertension. Biochem Biophys Res Commun 1992;184:9-15.

14. Bonithon-Kopp C, Ducimetiere P, Touboul PJ et al. Plasma angiotensin-converting enzyme activity and carotid wall thickening. Circulation 1994;89:952-954.

15. Casari G, Barlassina C, Cusi D et al. Association of the alpha-adducin locus with essential hypertension. Hypertension 1995;25:320-326.

16. Large V, Hellstrom L, Reynisdottir S et al. Human beta-2 adrenoceptor gene polymorphisms are highly frequent in obesity and associate with altered adipocyte beta-2 adrenoceptor function. J Clin Invest 1997;100:3005-3013.

17. Walston J, Silver K, Bogardus C et al. Time of onset of non-insulin-dependent diabetes mellitus and genetic variation in the beta 3-adrenergic-receptor gene. N Engl J Med 1995;333:343-347.

18. Bonnardeaux A, Davies E, Jeunemaitre X et al. Angiotensin II type 1 receptor gene polymorphisms in human essential hypertension. Hypertension 1994;24:63-69.

19. Hegele RA, Huang LS, Herbert PN, et al. Apolipoprotein B-gene DNA polymorphisms associated with myocardial infarction. N Engl J Med 1986;315:1509-1515.

20. Poduslo SE, Neal M, Herring K, Shelly J. The apolipoprotein CI A allele as a risk factor for Alzheimer's disease. Neurochem Res 1998;23:361-367.

21. Corder EH, Saunders AM, Strittmatter WJ et al. Gene dose of apolipoprotein E type 4 allele and the risk of Alzheimer's disease in late onset families. Science 1993;261: 921-923.

22. Cumming AM, Robertson FW. Polymorphism at the apoprotein-E locus in relation to risk of coronary disease. Clin Genet 1984;25:310-313.

23. Couderc R, Mahieux F, Bailleul S, Fenelon G, Mary R, Fermanian J. Prevalence of apolipoprotein E phenotypes in ischemic cerebrovascular disease: A case-control study. Stroke 1993;24:661-664.

24. Poirier J, Delisle MC, Quirion R et al. Apolipoprotein E4 allele as a predictor of cholinergic deficits and treatment outcome in Alzheimer disease. Proc Natl Acad Sci USA 1995;92:12260-12264.

25. Schachter F, Faure-Delanef L, Guenot F et al. Genetic associations with human longevity at the APOE and ACE loci. Nat Genet 1994;6:29-32.

26. Tut TG, Ghadessy FJ, Trifiro MA, Pinsky L, Yong EL. Long polyglutamine tracts in the androgen receptor are associated with reduced trans-activation, impaired sperm production, and male infertility. J Clin Endocrinol Metab 1997;82:37773782.

27. Stanford JL, Just JJ, Gibbs $M$ et al. Polymorphic repeats in the androgen receptor gene: molecular markers of prostate cancer risk. Cancer Res 1997;57:1194-1198.

28. Lehmann DJ, Johnston C, Smith AD. Synergy between the genes for butyrylcholinesterase K variant and apolipoprotein E4 in late-onset confirmed Alzheimer's disease. Hum Mol Genet 1997;6:1933-1936.

29. Smith MW, Dean M, Carrington M et al. Contrasting genetic influence of CCR2 and CCR5 variants on HIV-1 infection and disease progression. Hemophilia Growth and Development Study (HGDS), Multicenter AIDS Cohort Study (MACS), Multicenter Hemophilia Cohort Study (MHCS), San Francisco City Cohort (SFCC), ALIVE Study. Science 1997;277:959-965.

30. Grant SF, Reid DM, Blake G, Herd R, Fogelman I, Ralston SH. Reduced bone density and osteoporosis associated with a polymorphic Sp1 binding site in the collagen type I alpha 1 gene. Nat Genet 1996;14:203-205.

31. Gutierrez B, Bertranpetit J, Guillamat R et al. Association analysis of the catechol O-methyltransferase gene and bipolar affective disorder. Am J Psychiatry 1997;154: 113-115.

32. Li T, Sham PC, Vallada $\mathrm{H}$ et al. Preferential transmission of the high activity allele of COMT in schizophrenia. Psychiatr Genet 1996;6:131-133.

33. Donner H, Rau H, Walfish PG et al. CTLA4 alanine-17 confers genetic susceptibility to Graves' disease and to type 1 diabetes mellitus. J Clin Endocrinol Metab 1997;82:143-146.

34. Pullmann R, Jr., Lukac J, Skerenova M et al. Cytotoxic T lymphocyte antigen 4 (CTLA-4) dimorphism in patients with systemic lupus erythematosus. Clin Exp Rheumatol 1999;17:725-729.
35. Inoue N, Kawashima S, Kanazawa K, Yamada S, Akita H, Yokoyama M. Polymorphism of the NADH/NADPH oxidase p22 phox gene in patients with coronary artery disease. Circulation 1998;97:135-137.

36. Tamaki S, Iwai N, Tsujita Y, Kinoshita M. Genetic polymorphism of CYP11B2 gene and hypertension in Japanese. Hypertension 1999;33:266-270.

37. Ambrosone CB, Freudenheim JL, Graham S et al. Cytochrome P4501Al and glutathione S-transferase (M1) genetic polymorphisms and postmenopausal breast cancer risk. Cancer Res 1995;55:3483-34835.

38. Armstrong M, Daly AK, Cholerton S, Bateman DN, Idle JR. Mutant debrisoquine hydroxylation genes in Parkinson's disease. Lancet 1992;339:1017-1018.

39. Uematsu F, Kikuchi H, Motomiya $\mathrm{M}$ et al. Association between restriction fragment length polymorphism of the human cytochrome P450IIEl gene and susceptibility to lung cancer. Jpn J Cancer Res 1991;82:254-256.

40. Arinami T, Gao M, Hamaguchi H, Toru M. A functional polymorphism in the promoter region of the dopamine D2 receptor gene is associated with schizophrenia. Hum Mol Genet 1997;6:577-582.

41. Malhotra AK, Goldman D, Buchanan RW et al. The dopamine D3 receptor (DRD3) Ser9Gly polymorphism and schizophrenia: a haplotype relative risk study and association with clozapine response. Mol Psychiatry 1998;3:72-75.

42. Kennedy JL, Billett EA, Macciardi FM et al. Association study of dopamine D3 receptor gene and schizophrenia. Am J Med Genet 1995;60:558-562.

43. LaHoste GJ, Swanson JM, Wigal SB et al. Dopamine D4 receptor gene polymorphism is associated with attention deficit hyperactivity disorder. Mol Psychiatry 1996;1:121-124

44. Kurabayashi T, Tomita M, Matsushita $\mathrm{H}$ et al. Association of vitamin D and estrogen receptor gene polymorphism with the effect of hormone replacement therapy on bone mineral density in Japanese women. Am J Obstet Gynecol 1999;180:11151120.

45. Poort SR, Rosendaal FR, Reitsma PH, Bertina RM. A common genetic variation in the 3 '-untranslated region of the prothrombin gene is associated with elevated plasma prothrombin levels and an increase in venous thrombosis. Blood 1996;88: $3698-3703$.

46. De Stefano V, Chiusolo P, Paciaroni K et al. Prothrombin G20210A mutant genotype is a risk factor for cerebrovascular ischemic disease in young patients. Blood 1998;91:3562-3565.

47. Bertina RM, Koeleman BP, Koster T et al. Mutation in blood coagulation factor V associated with resistance to activated protein C. Nature 1994;369:64-67.

48. Dizon-Townson DS, Nelson LM, Easton K, Ward K. The factor V Leiden mutation may predispose women to severe preeclampsia. Am J Obstet Gynecol 1996;175:902905.

49. Moor E, Silveira A, van't Hooft F et al. Coagulation factor VII mass and activity in young men with myocardial infarction at a young age: Role of plasma lipoproteins and factor VII genotype. Arterioscler Thromb Vasc Biol 1995;15:655-664.

50. Salmon JE, Millard S, Schachter LA et al. Fc gamma RIIA alleles are heritable risk factors for lupus nephritis in African Americans. J Clin Invest 1996;97:1348-1354.

51. Hager J, Hansen L, Vaisse C et al. A missense mutation in the glucagon receptor gene is associated with non-insulin-dependent diabetes mellitus. Nat Genet 1995; 9:299-304.

52. Hattersley AT, Turner RC, Permutt MA et al. Linkage of type 2 diabetes to the glucokinase gene. Lancet 1992;339:1307-1310.

53. Siffert W, Rosskopf D, Siffert G et al. Association of a human G-protein beta3 subunit variant with hypertension. Nat Genet 1998;18:45-48.

54. Sperr WR, Huber K, Roden M, et al. Inherited platelet glycoprotein polymorphisms and a risk for coronary heart disease in young central Europeans. Thromb Res 1998;90:117-123.

55. Bell DA, Taylor JA, Paulson DF, Robertson CN, Mohler JL, Lucier GW. Genetic risk and carcinogen exposure: a common inherited defect of the carcinogen-metabolism gene glutathione S-transferase M1 (GSTM1) that increases susceptibility to bladder cancer. J Natl Cancer Inst 1993;85:1159-1164.

56. Anttila S, Hirvonen A, Husgafvel-Pursiainen K, Karjalainen A, Nurminen T, Vainio H. Combined effect of CYP1A1 inducibility and GSTM1 polymorphism on histological type of lung cancer. Carcinogenesis 1994;15:1133-1135.

57. Groop LC, Kankuri M, Schalin-Jantti C, et al. Association between polymorphism of the glycogen synthase gene and non-insulin-dependent diabetes mellitus. NEngl J Med 1993;328:10-14.

58. Hinney A, Ziegler A, Nothen MM, Remschmidt H, Hebebrand J. 5-HT2A receptor gene polymorphisms, anorexia nervosa, and obesity. Lancet 1997;350:1324-1325.

59. Arranz M, Collier D, Sodhi $\mathrm{M}$ et al. Association between clozapine response and allelic variation in 5-HT2A receptor gene. Lancet 1995;346:281-282.

60. Inayama $\mathrm{Y}$, Yoneda $\mathrm{H}$, Sakai $\mathrm{T}$ et al. Positive association between a DNA sequence variant in the serotonin 2A receptor gene and schizophrenia. Am J Med Genet 1996;67:103-105

61. Langdahl BL, Lokke E, Carstens M, Stenkjaer LL, Eriksen EF. Osteoporotic fractures are associated with an 86-base pair repeat polymorphism in the interleukin- 
1-receptor antagonist gene but not with polymorphisms in the interleukin-1beta gene. J Bone Miner Res 2000;15:402-414.

62. Zhu S, Chan-Yeung M, Becker AB et al. Polymorphisms of the IL-4, TNF-alpha, and Fcepsilon RIbeta genes and the risk of allergic disorders in at-risk infants. Am J Respir Crit Care Med 2000;161:1655-1659.

63. Hershey GK, Friedrich MF, Esswein LA, Thomas ML, Chatila TA. The association of atopy with a gain-of-function mutation in the alpha subunit of the interleukin-4 receptor. N Engl J Med 1997;337:1720-1725.

64. Tsukamoto K, Yoshida H, Watanabe S et al. Association of radial bone mineral density with CA repeat polymorphism at the interleukin 6 locus in postmenopausal Japanese women. J Hum Genet 1999;44:148-151.

65. Bell GI, Horita S, Karam JH. A polymorphic locus near the human insulin gene is associated with insulin-dependent diabetes mellitus. Diabetes 1984;33:176-183.

66. Hitman GA, Jowett NI, Williams LG, Humphries S, Winter RM, Galton DJ. Polymorphisms in the 5'-flanking region of the insulin gene and non-insulin-dependent diabetes. Clin Sci (Lond) 1984;66:383-388.

67. Imai Y, Fusco A, Suzuki Y et al. Variant sequences of insulin receptor substrate-1 in patients with noninsulin-dependent diabetes mellitus. J Clin Endocrinol Metab 1994;79:1655-1658.

68. Marian AJ, Brugada R, Kleiman NS. Platelet glycoprotein IIIa PlA polymorphism and myocardial infarction. N Engl J Med 1996;335:1071-1072; author reply 10731074.

69. Bowen T, Guy CA, Craddock $\mathrm{N}$ et al. Further support for an association between a polymorphic CAG repeat in the hKCa3 gene and schizophrenia. Mol Psychiatry 1998;3:266-269.

70. Li WD, Reed DR, Lee JH et al. Sequence variants in the 5 ' flanking region of the leptin gene are associated with obesity in women. Ann Hum Genet 1999;63:227234.

71. Thorn JA, Chamberlain JC, Alcolado JC et al. Lipoprotein and hepatic lipase gene variants in coronary atherosclerosis. Atherosclerosis 1990;85:55-60.

72. Vandevyver C, Raus P, Stinissen P, Philippaerts L, Cassiman JJ, Raus J. Polymorphism of the tumour necrosis factor beta gene in multiple sclerosis and rheumatoid arthritis. Eur J Immunogenet 1994;21:377-382.

73. Sullivan KE, Wooten C, Goldman D, Petri M. Mannose-binding protein genetic polymorphisms in black patients with systemic lupus erythematosus. Arthritis Rheum 1996;39:2046-2051.

74. Boylan KB, Takahashi N, Paty DW et al. DNA length polymorphism 5 ' to the myelin basic protein gene is associated with multiple sclerosis. Ann Neurol 1990; 27:291-297.

75. Frosst $\mathrm{P}, \mathrm{Blom} \mathrm{HJ}$, Milos $\mathrm{R}$ et al. A candidate genetic risk factor for vascular disease: a common mutation in methylenetetrahydrofolate reductase. Nat Genet 1995;10: 111-113.

76. Arruda VR, von Zuben PM, Chiaparini LC, Annichino-Bizzacchi JM, Costa FF. The mutation Ala677->Val in the methylene tetrahydrofolate reductase gene: a risk factor for arterial disease and venous thrombosis. Thromb Haemost 1997;77: $818-821$.

77. Wang XL, Sim AS, Badenhop RF, McCredie RM, Wilcken DE. A smoking-dependent risk of coronary artery disease associated with a polymorphism of the endothelial nitric oxide synthase gene. Nat Med 1996;2:41-45.

78. Sanghera DK, Aston CE, Saha N, Kamboh MI. DNA polymorphisms in two paraoxonase genes (PON1 and PON2) are associated with the risk of coronary heart disease. Am J Hum Genet 1998;62:36-44.

79. Deeb SS, Fajas L, Nemoto $\mathrm{M}$ et al. A Pro12Ala substitution in PPARgamma2 associated with decreased receptor activity, lower body mass index and improved insulin sensitivity. Nat Genet 1998;20:284-287.

80. Palmer MS, Dryden AJ, Hughes JT, Collinge J. Homozygous prion protein genotype predisposes to sporadic Creutzfeldt-Jakob disease. Nature 1991;352:340-342.

81. Wragg M, Hutton M, Talbot C. Genetic association between intronic polymorphism in presenilin-1 gene and late-onset Alzheimer's disease. Alzheimer's Disease Collaborative Group. Lancet 1996;347:509-512.

82. Wang H, Chu WS, Hemphill C, Elbein SC. Human resistin gene: molecular scanning and evaluation of association with insulin sensitivity and type 2 diabetes in Caucasians. J Clin Endocrinol Metab 2002;87:2520-2524.

83. Kalsheker NA, Hodgson IJ, Watkins GL, White JP, Morrison HM, Stockley RA. Deoxyribonucleic acid (DNA) polymorphism of the alpha 1-antitrypsin gene in chronic lung disease. BMJ (Clin Res Ed) 1987;294:1511-1514.

84. Morgan K, Morgan L, Carpenter K, et al. Microsatellite polymorphism of the alpha 1-antichymotrypsin gene locus associated with sporadic Alzheimer's disease. Hum Genet 1997;99:27-31.

85. Ishigami $\mathrm{T}$, Umemura $\mathrm{S}$, Iwamoto $\mathrm{T}$ et al. Molecular variant of angiotensinogen gene is associated with coronary atherosclerosis. Circulation 1995;91:951-954.

86. Jeunemaitre X, Soubrier F, Kotelevtsev YV et al. Molecular basis of human hypertension: role of angiotensinogen. Cell 1992;71:169-180.
87. Eriksson P, Kallin B, van't Hooft FM, Bavenholm P, Hamsten A. Allele-specific increase in basal transcription of the plasminogen-activator inhibitor 1 gene is associated with myocardial infarction. Proc Natl Acad Sci USA 1995;92:1851-1855.

88. Li SR, Baroni MG, Oelbaum RS, Stock J, Galton DJ. Association of genetic variant of the glucose transporter with non-insulin-dependent diabetes mellitus. Lancet 1988;2:368-370.

89. Lesch KP, Gross J, Franzek E, Wolozin BL, Riederer P, Murphy DL. Primary structure of the serotonin transporter in unipolar depression and bipolar disorder. Biol Psychiatry 1995;37:215-223.

90. Moffatt MF, Cookson WO. Tumour necrosis factor haplotypes and asthma. Hum Mol Genet 1997;6:551-554.

91. Herrmann SM, Ricard S, Nicaud V et al. Polymorphisms of the tumour necrosis factor-alpha gene, coronary heart disease and obesity. Eur J Clin Invest 1998;28:59_ 66.

92. Hohler T, Kruger A, Schneider PM et al. A TNF-alpha promoter polymorphism is associated with juvenile onset psoriasis and psoriatic arthritis. J Invest Dermato 1997;109:562-565.

93. Ilonen J, Merivuori $\mathrm{H}$, Reijonen $\mathrm{H}$ et al. Tumour necrosis factor-beta gene RFLP alleles in Finnish IDDM haplotypes. The Childhood Diabetes in Finland (DiMe) Study Group. Scand J Immunol 1992;36:779-783.

94. Heijmans BT, Westendorp RG, Droog S, Kluft C, Knook DL, Slagboom PE. Association of the tumour necrosis factor alpha-308G/A polymorphism with the risk of diabetes in an elderly population-based cohort. Genes Immun 2002;3:225-228.

95. Storey A, Thomas M, Kalita A et al. Role of a p53 polymorphism in the development of human papillomavirus-associated cancer. Nature 1998;393:229-234.

96. Esterbauer H, Oberkofler H, Liu YM et al. Uncoupling protein-1 mRNA expression in obese human subjects: the role of sequence variations at the uncoupling protein-1 gene locus. J Lipid Res 1998;39:834-844.

97. Cassell PG, Neverova M, Janmohamed S, et al. An uncoupling protein 2 gene variant is associated with a raised body mass index but not Type II diabetes. Dia betologia 1999;42:688-692.

98. Cassell PG, Saker PJ, Huxtable SJ et al. Evidence that single nucleotide polymorphism in the uncoupling protein 3 (UCP3) gene influences fat distribution in women of European and Asian origin. Diabetologia 2000;43:1558-1564.

99. Morrison NA, Qi JC, Tokita A et al. Prediction of bone density from vitamin D receptor alleles. Nature 1994;367:284-287.

100. Okuizumi K, Onodera O, Namba Y et al. Genetic association of the very low density lipoprotein (VLDL) receptor gene with sporadic Alzheimer's disease. Nat Genet 1995;11:207-209.

101. Neri Serneri GG, Boddi M, Poggesi L et al. Activation of cardiac renin-angiotensin system in unstable angina. J Am Coll Cardiol 2001;38:49-55.

102. Petit-Turcotte C, Stohl SM, Beffert U,et al. Apolipoprotein C-I expression in the brain in Alzheimer's disease. Neurobiol Dis 2001;8:953-963.

103. Isoe K, Urakami K, Sato K, Takahashi K. Apolipoprotein E in patients with dementia of the Alzheimer type and vascular dementia. Acta Neurol Scand 1996;93:133137.

104. Yamagata K, Urakami K, Ikeda K et al. High expression of apolipoprotein E mRNA in the brains with sporadic Alzheimer's disease. Dement Geriatr Cogn Disord 2001; 12:57-62.

105. Zarow C, Victoroff J. Increased apolipoprotein E mRNA in the hippocampus in Alzheimer disease and in rats after entorhinal cortex lesioning. Exp Neurol 1998 149:79-86.

106. Hernandez I, Sokolov BP. Abnormal expression of serotonin transporter mRNA in the frontal and temporal cortex of schizophrenics. Mol Psychiatry 1997;2:57-64.

107. Roberts DA, Balderson D, Pickering-Brown SM, Deakin JF, Owen F. The abundance of mRNA for dopamine D2 receptor isoforms in brain tissue from controls and schizophrenics. Brain Res Mol Brain Res 1994;25:173-175.

108. Tallerico T, Novak G, Liu IS, Ulpian C, Seeman P. Schizophrenia: elevated mRNA for dopamine D2(Longer) receptors in frontal cortex. Brain Res Mol Brain Res 2001;87:160-165.

109. Ilani T, Ben-Shachar D, Strous RD et al. A peripheral marker for schizophrenia: Increased levels of D3 dopamine receptor mRNA in blood lymphocytes. Proc Natl Acad Sci U S A 2001;98:625-628.

110. Kwak YT, Koo MS, Choi CH, Sunwoo I. Change of dopamine receptor mRNA expression in lymphocyte of schizophrenic patients. BMC Med Genet 2001;2:3.

111. Andreelli F, Laville M, Vega N, Riou JP, Vidal H. Regulation of gene expression during severe caloric restriction: lack of induction of $\mathrm{p} 85$ alpha phosphatidylinositol 3-kinase mRNA in skeletal muscle of patients with type II (non-insulin-dependent) diabetes mellitus. Diabetologia 2000;43:356-363.

112. Ducluzeau PH, Perretti N, Laville M et al. Regulation by insulin of gene expression in human skeletal muscle and adipose tissue. Evidence for specific defects in type 2 diabetes. Diabetes 2001;50:1134-1142.

113. Henry RR, Ciaraldi TP, Abrams-Carter L, Mudaliar S, Park KS, Nikoulina SE. Glycogen synthase activity is reduced in cultured skeletal muscle cells of non- 
insulin-dependent diabetes mellitus subjects. Biochemical and molecular mechanisms. J Clin Invest 1996;98:1231-126.

114. Huang X, Vaag A, Hansson M, Weng J, Laurila E, Groop L. Impaired insulinstimulated expression of the glycogen synthase gene in skeletal muscle of type 2 diabetic patients is acquired rather than inherited. J Clin Endocrinol Metab 2000; 85:1584-1590.

115. Lofman M, Yki-Jarvinen H, Parkkonen M et al. Increased concentrations of glycogen synthase protein in skeletal muscle of patients with NIDDM. Am J Physiol 1995;269:E27-E32.

116. Vestergaard H, Bjorbaek C, Andersen PH, Bak JF, Pedersen O. Impaired expression of glycogen synthase mRNA in skeletal muscle of NIDDM patients. Diabetes 1991; 40:1740-1745.

117. Vestergaard H, Lund S, Larsen FS, Bjerrum OJ, Pedersen O. Glycogen synthase and phosphofructokinase protein and mRNA levels in skeletal muscle from insulinresistant patients with non-insulin-dependent diabetes mellitus. J Clin Invest 1993; 91:2342-50.

118. Burnet PW, Eastwood SL, Harrison PJ. 5-HT1A and 5-HT2A receptor mRNAs and binding site densities are differentially altered in schizophrenia. Neuropsychopharmacology 1996;15:442-455.

119. Hernandez I, Sokolov BP. Abnormalities in 5-HT2A receptor mRNA expression in frontal cortex of chronic elderly schizophrenics with varying histories of neuroleptic treatment. J Neurosci Res 2000;59:218-225.

120. Glare EM, Divjak M, Rolland JM, Walters EH. Asthmatic airway biopsy specimens are more likely to express the IL-4 alternative splice variant IL-4delta2. J Allergy Clin Immunol 1999;104:978-982.

121. Humbert M, Durham SR, Ying S et al. IL-4 and IL-5 mRNA and protein in bronchial biopsies from patients with atopic and nonatopic asthma: evidence against "intrinsic" asthma being a distinct immunopathologic entity. Am J Respir Crit Care Med 1996;154:1497-1504.

122. Kotsimbos TC, Ernst P, Hamid QA. Interleukin-13 and interleukin-4 are coexpressed in atopic asthma. Proc Assoc Am Physicians 1996;108:368-373.

123. Minshall EM, Hogg JC, Hamid QA. Cytokine mRNA expression in asthma is not restricted to the large airways. J Allergy Clin Immunol 1998;101:386-390.

124. Olivenstein R, Taha R, Minshall EM, Hamid QA. IL-4 and IL-5 mRNA expression in induced sputum of asthmatic subjects: comparison with bronchial wash. $\mathrm{J} \mathrm{Al}$ lergy Clin Immunol 1999;103:238-245.

125. Robinson DS, Hamid Q, Ying S et al. Predominant TH2-like bronchoalveolar T-lymphocyte population in atopic asthma. N Engl J Med 1992;326:298-304.

126. Kotsimbos TC, Ghaffar O, Minshall EM et al. Expression of the IL-4 receptor alpha-subunit is increased in bronchial biopsy specimens from atopic and nonatopic asthmatic subjects. J Allergy Clin Immunol 1998;102:859-866.

127. Hamilton BS, Paglia D, Kwan AY, Deitel M. Increased obese mRNA expression in omental fat cells from massively obese humans. Nat Med 1995;1:953-956.

128. Krempler F, Breban D, Oberkofler $\mathrm{H}$ et al. Leptin, peroxisome proliferator-activated receptor-gamma, and CCAAT/enhancer binding protein-alpha mRNA expression in adipose tissue of humans and their relation to cardiovascular risk factors. Arterioscler Thromb Vasc Biol 2000;20:443-449.

129. Montague CT, Prins JB, Sanders L, Digby JE, O'Rahilly S. Depot- and sex-specific differences in human leptin mRNA expression: implications for the control of regional fat distribution. Diabetes 1997;46:342-7.

130. Considine RV, Considine EL, Williams CJ et al. Evidence against either a premature stop codon or the absence of obese gene mRNA in human obesity. JClin Invest 1995;95:2986-2988.

131. Considine RV, Sinha MK, Heiman ML et al. Serum immunoreactive-leptin concentrations in normal-weight and obese humans. N Engl J Med 1996;334:292-295.

132. Lonnqvist F, Arner P, Nordfors L, Schalling M. Overexpression of the obese (ob) gene in adipose tissue of human obese subjects. Nat Med 1995;1:950-953.

133. Vidal H, Auboeuf D, De Vos P et al. The expression of ob gene is not acutely regulated by insulin and fasting in human abdominal subcutaneous adipose tissue. J Clin Invest 1996;98:251-255.

134. Xu M, Zhong G, Fu Z et al. Molecular cloning, sequencing and expression of obese gene in the Chinese. Chin Med J (Engl) 2000;113:350-353.

135. Auboeuf D, Rieusset J, Fajas L, et al. Tissue distribution and quantification of the expression of mRNAs of peroxisome proliferator-activated receptors and liver $\mathrm{X}$ receptor-alpha in humans: no alteration in adipose tissue of obese and NIDDM patients. Diabetes 1997;46:1319-27.
136. Kruszynska YT, Mukherjee R, Jow L, Dana S, Paterniti JR, Olefsky JM. Skeletal muscle peroxisome proliferator- activated receptor-gamma expression in obesity and non- insulin-dependent diabetes mellitus. J Clin Invest 1998;101:543-548.

137. Park KS, Ciaraldi TP, Abrams-Carter L, Mudaliar S, Nikoulina SE, Henry RR. PPAR-gamma gene expression is elevated in skeletal muscle of obese and type II diabetic subjects. Diabetes 1997;46:1230-1234.

138. Sewter C, Blows F, Considine R, Vidal-Puig A, O'Rahilly S. Differential effects of adiposity on peroxisomal proliferator-activated receptor gammal and gamma2 messenger ribonucleic acid expression in human adipocytes. J Clin Endocrinol Metab 2002;87:4203-4207.

139. Vidal-Puig AJ, Considine RV, Jimenez-Linan $\mathrm{M}$ et al. Peroxisome proliferatoractivated receptor gene expression in human tissues. Effects of obesity, weight loss, and regulation by insulin and glucocorticoids. J Clin Invest 1997;99:2416-2422.

140. Johnston JA, Froelich S, Lannfelt L, Cowburn RF. Quantification of presenilin-1 mRNA in Alzheimer's disease brains. FEBS Lett 1996;394:279-284.

141. Ikeda K, Urakami K, Isoe K, Ohno K, Nakashima K. The expression of presenilin-1 mRNA in skin fibroblasts from Alzheimer's disease. Dement Geriatr Cogn Disord 1998;9:145-148.

142. Ikeda K, Urakami K, Arai $\mathrm{H}$ et al. The expression of presenilin 1 mRNA in skin fibroblasts and brains from sporadic Alzheimer's disease. Dement Geriatr Cogn Disord 2000;11:245-250.

143. Davis D, Liyou N, Lockwood D, Johnson A. Angiotensinogen genotype, plasma protein and mRNA concentration in isolated systolic hypertension. Clin Genet 2002;61:363-368.

144. Sun Y, Zhang L, Johnston NL, Torrey EF, Yolken RH. Serial analysis of gene expression in the frontal cortex of patients with bipolar disorder. BrJ Psychiatry Suppl 2001;41:s137-s141.

145. Hube F, Birgel M, Lee YM, Hauner H. Expression pattern of tumour necrosis factor receptors in subcutaneous and omental human adipose tissue: role of obesity and non-insulin-dependent diabetes mellitus. Eur J Clin Invest 1999;29:672-678.

146. Hotamisligil GS, Arner P, Caro JF, Atkinson RL, Spiegelman BM. Increased adipose tissue expression of tumor necrosis factor-alpha in human obesity and insulin resistance. J Clin Invest 1995;95:2409-2415.

147. Kern PA, Saghizadeh M, Ong JM, Bosch RJ, Deem R, Simsolo RB. The expression of tumor necrosis factor in human adipose tissue: Regulation by obesity, weight loss, and relationship to lipoprotein lipase. J Clin Invest 1995;95:2111-2119.

148. Kern PA, Ranganathan S, Li C, Wood L, Ranganathan G. Adipose tissue tumor necrosis factor and interleukin-6 expression in human obesity and insulin resistance. Am J Physiol Endocrinol Metab 2001;280:E745-E751.

149. Koistinen HA, Bastard JP, Dusserre E, et al. Subcutaneous adipose tissue expression of tumour necrosis factor-alpha is not associated with whole body insulin resistance in obese nondiabetic or in type-2 diabetic subjects. Eur J Clin Invest 2000;30:302-310.

150. Oberkofler H, Dallinger G, Liu YM, Hell E, Krempler F, Patsch W. Uncoupling protein gene: quantification of expression levels in adipose tissues of obese and non-obese humans. J Lipid Res 1997;38:2125-2133.

151. Oberkofler H, Liu YM, Esterbauer H, Hell E, Krempler F, Patsch W. Uncoupling protein-2 gene: reduced mRNA expression in intraperitoneal adipose tissue of obese humans. Diabetologia 1998;41:940-946.

152. Millet L, Vidal H, Andreelli F et al. Increased uncoupling protein-2 and - 3 mRNA expression during fasting in obese and lean humans. J Clin Invest 1997;100:26652670 .

153. Nordfors L, Hoffstedt J, Nyberg B et al. Reduced gene expression of UCP2 but not UCP3 in skeletal muscle of human obese subjects. Diabetologia 1998;41:935-939.

154. Sbraccia P, D'Adamo M, Leonetti F, et al. Relationship between plasma free fatty acids and uncoupling protein-3 gene expression in skeletal muscle of obese subjects: in vitro evidence of a causal link. Clin Endocrinol (Oxf) 2002;57:199-207.

155. Vidal-Puig A, Rosenbaum M, Considine RC, Leibel RL, Dohm GL, Lowell BB. Effects of obesity and stable weight reduction on UCP2 and UCP3 gene expression in humans. Obes Res 1999;7:133-140.

156. Esterbauer H, Oberkofler H, Dallinger G et al. Uncoupling protein-3 gene expression: reduced skeletal muscle mRNA in obese humans during pronounced weight loss. Diabetologia 1999;42:302-309.

157. Millet L, Vidal H, Larrouy D, Andreelli F, Laville M, Langin D. mRNA expression of the long and short forms of uncoupling protein-3 in obese and lean humans. Diabetologia 1998;41:829-832. 